\title{
Procaine-The Controversial Geroprotector Candidate: New Insights Regarding Its Molecular and Cellular Effects
}

\author{
Daniela Gradinaru $\left(\mathbb{D},{ }^{1}\right.$ Anca Ungurianu ${ }^{(D)},{ }^{1}$ Denisa Margina ${ }^{(D)}{ }^{1}$ \\ Maria Moreno-Villanueva ${ }^{(D)},{ }^{2,3}$ and Alexander Bürkle $\mathbb{i D}^{3}$ \\ ${ }^{1}$ Department of Biochemistry, Faculty of Pharmacy, Carol Davila University of Medicine and Pharmacy, \\ RO-020956 Bucharest, Romania \\ ${ }^{2}$ Department of Sport Science, Human Performance Research Centre, University of Konstanz, D-78457 Konstanz, Germany \\ ${ }^{3}$ Department of Biology, Molecular Toxicology Group, University of Konstanz, D-78457 Konstanz, Germany
}

Correspondence should be addressed to Daniela Gradinaru; daniela.gradinaru@umfcd.ro

and Maria Moreno-Villanueva; maria.moreno-villanueva@uni-konstanz.de

Received 7 May 2021; Revised 26 June 2021; Accepted 12 July 2021; Published 31 July 2021

Academic Editor: Raquel Rodriguez-Diez

Copyright (C) 2021 Daniela Gradinaru et al. This is an open access article distributed under the Creative Commons Attribution License, which permits unrestricted use, distribution, and reproduction in any medium, provided the original work is properly cited.

\begin{abstract}
Since its discovery in 1905 and its employment in everyday medical practice as a local anesthetic, to its highly controversial endorsement as an "anti-aging" molecule in the sixties and seventies, procaine is part of the history of medicine and gerontoprophylaxis. Procaine can be considered a "veteran" drug due to its long-time use in clinical practice, but is also a molecule which continues to incite interest, revealing new biological and pharmacological effects within novel experimental approaches. Therefore, this review is aimed at exploring and systematizing recent data on the biochemical, cellular, and molecular mechanisms involved in the antioxidant and potential geroprotective effects of procaine, focusing on the following aspects: (1) the research state-of-the-art, through an objective examination of scientific literature within the last 30 years, describing the positive, as well as the negative reports; (2) the experimental data supporting the beneficial effects of procaine in preventing or alleviating age-related pathology; and (3) the multifactorial pathways procaine impacts oxidative stress, inflammation, atherogenesis, cerebral age-related pathology, DNA damage, and methylation. According to reviewed data, procaine displayed antioxidant and cytoprotective actions in experimental models of myocardial ischemia/reperfusion injury, lipoprotein oxidation, endothelial-dependent vasorelaxation, inflammation, sepsis, intoxication, ionizing irradiation, cancer, and neurodegeneration. This analysis painted a complex pharmacological profile of procaine: a molecule that has not yet fully expressed its therapeutic potential in the treatment and prevention of aging-associated diseases. The numerous recent reports found demonstrate the rising interest in researching the multiple actions of procaine regulating key processes involved in cellular senescence. Its beneficial effects on cell/tissue functions and metabolism could designate procaine as a valuable candidate for the well-established Geroprotectors database.
\end{abstract}

\section{Introduction}

Procaine was synthesized by Alfred Einhorn in 1905 and introduced in clinical practice as Novocain, soon becoming a local anesthetic prototype. Around the 1950s, a large number of accumulated data emphasized the surprising diversity of nonanesthetic effects exerted by procaine, which came to the attention of various medical research schools in Eastern and Western Europe, many doctors exploring, regardless of borders, the beneficial properties of procaine: Vishnevsky and Speransky (Russia); Huneke and Lüth (Germany); Leriche, Dos Ghali, and Hazard (France); Danielopolu and Parhon (Romania) [1-9]. Between 1946 and 1956, Ana Aslan described a significant number of procaine beneficial actions exerted on cellular functions and metabolism, following long-term treatment in low doses, highlighting its "rejuvenating" effects, and developed Gerovital H3 (GH3) - an original procaine-based pharmaceutical formulation [10-12]. Due to 
these findings, procaine which was known only for its anesthetic properties became one of the most disputed medical developments of the sixties and seventies in the field of "anti-aging" therapy [13-15].

While aging per se seems to be the predominant risk factor for most diseases that limit healthspan, the human lifespan can be viewed as a series of gene-environment interactions that inevitably lead to an earlier or later onset of agingrelated conditions such as type 2 diabetes, atherosclerosis and cardiovascular diseases, depression, neurodegeneration and cognitive decline, cancer, sarcopenia, osteoarthritis, and osteoporosis [16, 17].

Recent progresses in the field of aging research led to the development of a new class of drugs-geroprotectors, with the ability to target fundamental mechanisms of aging common to multiple age-related diseases, such as response to oxidative damage, inflammation, hypermethylation, cellular senescence, and autophagy [18]. Moskalev et al. (2015) established the first public database of geroprotectors (http:// geroprotectors.org) that indexes the most relevant experiments involving over 200 well-established geroprotectors or possible candidates that could extend the healthy lifespan and repair or reduce aging-related damage in model organisms [19]. As primary selection criteria for the potential geroprotectors, the following characteristics were recognized: (1) the ability to increase lifespan; (2) the capacity to ameliorate molecular, cellular, and physiological biomarkers to a younger state or slow the progression of age-related change of these markers; (3) a therapeutic lifespan-extending dose of geroprotector, which should be several orders of magnitude less than the toxic dose; and (4) the capacity to improve the health-related quality of life of the patient, from a physical, mental, emotional, and social viewpoint [20]. The compliance of procaine with most of these criteria would allow it to be a potential "geroprotector" candidate.

Although GH3 was internationally launched in 1956, simultaneously with the development of the Free Radical Theory of Aging by Denham Harman [21], the study of the antioxidant action of procaine and GH3 was documented only after 1980, in various experimental designs, which proved its capacity of limiting the generation of reactive oxygen species (ROS) and lipid peroxidation [22-29]. Recently, the radioprotective effects of procaine and $\mathrm{GH} 3$ were reported in vitro in human lymphocytes isolated from young and aged individuals [29]. Besides its antioxidant, cytoprotective, anti-inflammatory, and antiatherogenic effects, at cellular and molecular levels, procaine has multiple targets, supporting a large number of potential "geroprotective" effects $[30,31]$. Older and more recent data revealed that procaine and its metabolites modulate several biochemical and cellular processes like mitochondrial structure and function [32-34], cholesterol biosynthesis [35], monoamine oxidase (MAO) activity [36, 37], and DNA methylation [38-41].

Procaine is part of the history of medicine and gerontoprophylaxis, an old-timer of clinical practice, but still a molecule with great potential which continues to reveal new biological and pharmacological effects within novel experimental approaches. Therefore, the aim of this review is to explore and systematize data on biochemical, cellular, and molecular mechanisms involved in the antioxidant and alleged geroprotective actions of procaine and $\mathrm{GH} 3$, focusing on the following aspects: (1) the research state-of-the-art, through an objective examination of scientific literature for the last 30 years-describing both positive and negative research outcomes; (2) the experimental data supporting the beneficial effects of procaine in preventing the agerelated pathology; and (3) the multitude of ways procaine impacts oxidative stress, atherogenesis, cerebral age-related pathology, and DNA methylation.

\section{Procaine and Gerovital H3-From Anesthetic to "Anti-Aging"}

As early as 1892, the German chemist Alfred Einhorn began to model on the structural formula of cocaine, an alkaloid extracted from the leaves of Erythroxylum coca and the first known local anesthetic, in order to obtain less addictive molecules, but with similar or enhanced anesthetic qualities. Thus, he synthesized procaine-the first injectable anesthetic, introduced in medical practice under the trade name of Novocaine, which means "new cocaine," from the Latin nov- "new" and -caine, a common ending for alkaloids used as anesthetics [42].

Therapeutic effects pointed out after systemic administration and anesthetic properties, illustrate different aspects of procaine pharmacodynamics, being determined by dosage and administration routes. It was known by then that the systemic administration of procaine at high concentrations leads to a local anesthetic effect. Of all the local anesthetics, procaine was the least toxic [43-45]. In 1949, the physiologists Danielopolu and Simionescu highlighted procaine's multiplicity of actions, stating that it "exerts uniform action in the organism, restores and enhances active vital processes and local resistance" [8]. Among the researchers who took a close look at procaine, Ana Aslan noticed another quality of procaine: its geroprotective properties. In 1951, she began treating a group of selected patients with $2 \%$ procaine, reporting several "rejuvenating" effects in elderly patients: memory enhancement, alleviation of depression, hair repigmentation, better skin tone, and an overall improvement of their condition $[10,11]$; all these observations resulted, at that stage, in regarding procaine as "a useful prophylactic and therapeutic substance in the fight against old age" [9, 12]. At the same time, due to its short-term anesthetic effect and need for repeated administration to achieve longer anesthesia, observations regarding the interesting changes occurring following prolonged use started to emerge in the medical community [46]. Aslan sought to alter procaine pharmacokinetics in order to increase its stability in the body, prolong its action and explore its full therapeutic potential. In this purpose, in 1956, a pharmaceutical formulation containing $2 \%$ procaine hydrochloride, $0.12 \%$ benzoic acid, $0.10 \%$ potassium metabisulphite, and $0.01 \%$ disodium phosphate (as excipients and stabilizers), with a $\mathrm{pH}$ of 3.3, was designed and marketed as GH3 [12, 30]. Pharmacokinetic studies revealed that serum procaine levels are higher after the administration of GH3 than following the one of a procaine solution of similar concentration [47, 48]. Although the 
studies regarding the effects of GH3 were developed within a large prophylaxis campaign and there were clinical trials involving thousands of elderly subjects, some in the medical world of the 1960s contradicted the so-claimed beneficial effects of the treatment developed by Aslan [13]. The negative outlook and backlash were caused because, at that time, behind Gerovital was more marketing for a "miraculous anti-aging product" than indisputable scientific evidence. In 1982, following the study commissioned by the National Institute on Aging, the U.S. Food and Drug Administration (FDA) banned GH3 for "anti-aging and associated claims" [13-15].

\section{Procaine Pharmacokinetics and Metabolism}

Procaine is a drug with limited distribution and tissue uptake and a short duration of action: during a continuous intravenous infusion of $2 \%$ procaine, the steady-state plasma level is achieved within 20 to 30 minutes. Following the termination of the administration, drug concentration decreases rapidly, with a distribution half-life (t1/2 alpha) of $2.49 \pm 0.36$ minutes and an elimination half-life (t1/2 beta) of $7.69 \pm$ 0.99 minutes [49]. At systemic level, procaine is hydrolyzed to diethyl-amino-ethanol (DEAE) and para-aminobenzoic acid (PABA), as primary metabolites, by the enzyme pseudocholinesterase [50] (Figure 1). In different organs, procaine is hydrolyzed under the microsomal carboxylesterases [51, 52]. DEAE displays local anesthetic activity [53].

Procaine hydrolysis represents an important feature that could support some of its effects on cellular functions and metabolism, as the primary and secondary metabolites could have additional pharmacologic actions or participate as precursors in the synthesis of essential biomolecules. Kietzmann and Kaemmerer (1989) tested the influence of orally-administrated procaine hydrochloride on intermediary metabolism in rats and pointed out the fact that the ratio of acetyl coenzyme A to coenzyme A clearly was enhanced in the liver and, to a minor extent, in the cerebellum. Also, procaine hydrochloride, GH3, as well as DEAE increased, in a dose- and time-dependent mode, the hepatic incorporation rate of amino acids in protein, while PABA yielded no effect [54].

A very attractive hypothesis, which needs more studies and scientific evidence, is the second stage of procaine metabolism (remarkable from the pharmacodynamics viewpoint): the possible generation of ethanolamine from DEAE. Ethanolamine is a possible precursor in the biosynthesis of membrane phospholipids (phosphatidylethanolamine and phosphatidylcholine), which can be converted into the neurotransmitter acetylcholine (Ach) [55-57].

\section{Aging, Age-Related Diseases, and Antioxidant Action of Procaine and GH3}

The "Free Radical Hypothesis of Aging" was put forward 65 years ago, being later revised to the theory known as the "Oxidative Stress Hypothesis" [21, 58, 59]. According to these theories, oxidative stress is caused by the imbalance between the reactive oxygen species (ROS) production and

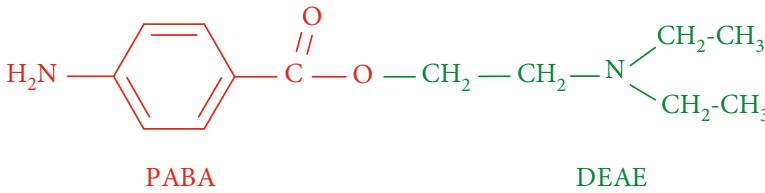

FIgURE 1: Chemical structure of procaine, ester of paraaminobenzoic acid (PABA) with diethyl-amino-ethanol (DEAE).

the biological system's ability to counteract, with an appropriate antioxidant defense, resulting in the oxidative damage of cell membranes and other structures such as lipids, lipoproteins, proteins, and DNA [60]. Multiple endogenous sources such as xanthine oxidase, NADPH oxidase, and the mitochondrial respiratory chain can be involved in ROS generation. A variety of environmental stimuli, such as radiation, pathogen infections, and exposure to xenobiotics, can also enhance in vivo ROS production [59].

Since many age-related diseases/geriatric syndromes are associated with oxidative stress, and the consequent cellular damage, limiting its intensity became a major area of interest and a common therapeutic target of aging-related pharmaceutical research [61]. Among the strategies of disease prevention and geroprotective therapies, antioxidants are currently still of cutting-edge interest. New experimental approaches, along sensitive and specific methods, are employed in testing and evaluating the actions of natural antioxidant compounds or drugs on alleviating oxidative stress under biological conditions similar to those existing in vivo $[62,63]$.

The antioxidant action of procaine and GH3 has been supported by in vitro and in vivo studies, in different research models demonstrating the inhibition of ROS generation and lipid peroxidation, associated with a modulating effect on antioxidant enzymes and nonenzymatic antioxidants.

4.1. ROS Generation and Lipid Peroxidation-In Vitro Studies. In 1989, Rusu and Lupeanu demonstrated for the first time the antioxidant action of procaine, but also of the other GH3 ingredients, namely, potassium metabisulphite and benzoic acid. The inhibitory effect of these products on ROS generation was evaluated in vitro using Nishikimi's electron carrier system generating the superoxide radical $\left(\mathrm{O}_{2}{ }^{-}\right)$, comprising reduced nicotinamide adenine dinucleotide (NADH), phenazine methosulfate (PMS), and nitroblue tetrazolium (NBT). GH3 and procaine inhibited the generation of $\mathrm{O}_{2}{ }^{--}$in the presence of increasing concentrations of procaine hydrochloride equivalents $(0.2,0.4,0.6,0.8$, 1.0 , and $2.0 \mathrm{mM}$ ), compared to $\mathrm{Cu} / \mathrm{Zn}$-superoxide dismutase (SOD) - the antioxidant enzyme that detoxifies superoxide physiologically. The strongest antioxidant effect (68\% inhibition of NBT reduction) was exerted at $2.0 \mathrm{mM}$ GH3 [22].

It was proposed that toxic $\mathrm{O}_{2}$ metabolites generated by xanthine oxidase $(\mathrm{XO})$ contribute in vivo to the development of ischemia-reperfusion injury in a variety of tissues [59]. Gradinaru et al. (2009) examined the antioxidant effects of procaine and $\mathrm{GH} 3$ with regard to $\mathrm{O}_{2}{ }^{--}$generation in a physiologic enzymatic system: xanthine - XO - 2-(4- 
iodophenyl)-3-(4-nitrophenol)-5-phenyltetrazolium chloride (INT). GH3 inhibited INT reduction in a dosedependent manner, at degrees comparable to SOD. At $10 \mathrm{mM}$, the maximum inhibition of $\mathrm{O}_{2}{ }^{--}$generation was achieved by $\mathrm{GH} 3(62 \%)$, whereas procaine hydrochloride had a slight (5\%) inhibitory effect [25].

Previously, Jinnouchi et al. (2005) studied whether local anesthetics inhibit the priming of neutrophils induced by lipopolysaccharide (LPS). They found that $4.0 \mathrm{mM}$ procaine, $3.0 \mathrm{mM}$ lidocaine, $0.5 \mathrm{mM}$ bupivacaine, or $0.1 \mathrm{mM}$ tetracaine inhibited by $50 \%$ the release of $\mathrm{O}_{2}{ }^{-{ }^{-}}$, in response to triggering by the chemotactic peptide $\mathrm{N}$-formyl-methionyl-leucyl phenylalanine (fMLP) [64]. Librowski and Moniczewski (2010) examined comparatively the antioxidant effect of several local anesthetics. The potency of scavenging radicals, measured as relative scavenging effect (\%) of the $2,2^{\prime}$-azino-bis (3-ethylbenzothiazoline-6-sulfonic acid) diammonium salt (ABTS) cation, decreased in the following order: tetracaine $>$ procaine $>$ lignocaine $>$ benzocaine (by 99, 38, 21, and $20 \%$, respectively, at a concentration of $10 \mathrm{mM}$ ) [27].

Lee et al. (2010) tested in vitro the antioxidant effect of procaine and lidocaine on endothelial-dependent relaxation in the rabbit aorta to examine if their antioxidizing effects could suppress or reduce the ROS-induced endothelial damage. The isolated aortic rings were pretreated with procaine or lidocaine $\left(10^{-5} \mathrm{M}\right.$ to $\left.3 \times 10^{-3} \mathrm{M}\right)$ and subjected to precontraction with phenylephrine $(\mathrm{PE})$. The changes (\%) of the aortic tone by acetylcholine (ACh) administration before (control) and after ROS exposure were compared. Their results suggested that procaine and lidocaine dosedependently preserved endothelium-dependent vasorelaxation against ROS attack, procaine potentially acting via hydrogen peroxide scavenging, as part of its protection mechanism [26]. Takaishi et al. (2013) evaluated the effects of local anesthetics procaine and lidocaine on nitric oxide (NO) production in a bovine aortic endothelial cells culture (BAEC), under proinflammatory conditions. In bradykinin and Ach stimulated cells, $10 \mathrm{mM}$ procaine significantly inhibited NO production by $35 \%$, whereas in cells incubated with interleukin-1 beta (IL-1 $\beta$ ) and LPS, $10 \mathrm{mM}$ procaine significantly inhibited NO production by $15 \%$. Authors suggested that the inhibitory effects of procaine on NO production are partially due to the suppression of L-arginine uptake [65].

The antioxidant action of GH3 and procaine under proinflammatory conditions was recently tested by Ungurianu et al. (2020) using a human lymphoblastoid cell line as experimental model. Membrane lipid peroxidation in Jurkat cells was induced by cumene hydroperoxide $(\mathrm{CuOOH})$ and assessed with diphenyl-1-pyrenylphosphine (DPPP), a sensitive fluorescent probe. The preincubation of Jurkat cells with $2.5,5.0$, and, respectively, $10 \mathrm{mM}$ procaine or $\mathrm{GH} 3$ effectively reduced the generation of cell membrane lipoperoxides, but $\mathrm{GH} 3$ was more effective than procaine especially at the lowest concentration $(2.5 \mathrm{mM})$, when $\mathrm{GH} 3$ prevented lipid peroxidation by $21 \%$, versus only $5 \%$ for procaine. At 5 and $10 \mathrm{mM}$, procaine and GH3 showed similar patterns of antioxidant action [29].

Ionizing radiation contributes to ROS generation and DNA damage which is known to be one of the mechanisms responsible for increasing mutagenesis risk, vascular aging, cancer, and neurodegenerative diseases [66-69]. The radioprotective effects of procaine and $\mathrm{GH} 3(0.25,0.5$, and $1 \mathrm{mM}$ ) on the formation of endogenous and X-ray-induced DNA strand breaks in peripheral blood mononuclear cells (PBMCs) isolated from young and elderly individuals were recently investigated. Interestingly, at low concentrations $(0.25,0.5$, and $1 \mathrm{mM}), \mathrm{GH} 3$ showed the strongest radioprotective effects in PBMCs from young subjects, while procaine reduced the endogenous amount of DNA strand breaks more pronounced in aged individuals. Concentrations of procaine and $\mathrm{GH} 3$ of $3 \mathrm{mM}$ and higher ( 5 and $10 \mathrm{mM}$ ) showed a genotoxic effect as measured by DNA strand breaks formation, using the automated fluorescence-detected alkaline DNA unwinding (FADU) assay [29].

4.2. Mitochondria Function. In recent years, it was reported that mitochondria, besides being the main cellular source of ROS, might also be the most relevant target of free radicals, playing a central role in aging [70]. Mitochondria are particularly prone to lipid peroxidation $[71,72]$, and there is a strong link between mitochondrial metabolism, oxidant species formation, and the biology of aging [73-75]. Mitochondrial ROS also increases with age, and the oxidative stressdependent decline of cell functions is partially related to the impairment of the mitochondrial respiratory chain [76-78].

As an anesthetic, procaine binds to membrane constituents and modulates a series of ion channels, interacts with membrane phospholipids, and induces concentrationdependent changes in membrane fluidity [42, 79-81]. Moreover, mitochondria, which are considered the powerhouses of the cell, are a potential target for general and local anesthetics [34]. At the cellular and molecular levels, procaine and its metabolites affect several biochemical and cellular processes like membrane conductance [81], oxidative phosphorylation [32], mitochondrial function and structure [33], or fatty acids oxidation [82].

Following an in vivo treatment (1 mg procaine/100 g body weight, for 3 days), procaine facilitated oxygen transport towards the mitochondrial matrix by modifying the membrane structure of brain mitochondria in both old and young rats [32]. The mitochondrial ATP-sensitive potassium channel (mitoKATP) is an important component of the mitochondria, whose opening is caused by a calcium signal or by brief episodes of ischemia-reperfusion [34]. de Klaver et al. (2006) demonstrated in human microvascular endothelial cells that tetracaine and procaine had no protective effect against the cell injury induced by inflammation (LPS) and inhibited the activation of mitoKATP channels [83].

Tarba and Crăcium (1990) pointed out, in isolated rat liver mitochondria, a stimulation of the basal state (respiration before ADP addition) in presence of low concentration $(1 \mathrm{mM})$ of procaine. Moreover, procaine had a biphasic effect, exerting a slight stimulation of state- 3 respiration (ADP present) at low and moderate concentrations $(\leq 1 \mathrm{mM})$ and an inhibition at higher concentrations $(>1 \mathrm{mM})$. Besides, electron microscopy confirmed this inhibitory effect, showing an abundance of either swollen or supercondensed mitochondria, with many membrane ruptures. At very low 
procaine concentrations $(0.01-0.1 \mathrm{mM})$, the stimulation of the two respiration states is approximately equal and thus the uncoupling effect is absent or negligible [33]. High concentrations $(>10 \mathrm{mM})$ of procaine and $\mathrm{GH} 3$ inhibited the uncoupling effect of 2,4-dinitrophenol (2-DNP) on oxidative phosphorylation and stimulated the respiratory activity and induced membrane rigidity thus allowing preferential oxygen diffusion and acceleration of free radical reactions, whereas low concentrations facilitated diffusion of sulfhydryl ( $\mathrm{SH}$ ) containing-compounds, exerting protective effects against lipid peroxidation [84]. Since mitochondrial injury is considered a central event in the early stages of the nephrotoxic effect of the antineoplastic drug cisplatin, Zicca et al. (2002) demonstrated that procaine hydrochloride was able to protect mice and rats through its accumulation in kidneys, followed by coordination with cisplatin (or its hydrolysis metabolites) and formation of a less toxic platinum compound [85]. Previously, Zhang and Lindup (1994) pointed out that procaine $(2 \mathrm{mM})$, DEAE, and PABA protected against the rat kidney cellular damage caused by cisplatin and inhibited by 24,30 , and $22 \%$, respectively, the cisplatin-induced mitochondrial lipid peroxidation, without any changes regarding the mitochondrial protein sulfhydryl groups (protein-SH) [86].

Studies conducted by Onizuka et al. (2010) in rat dorsal root ganglion neurons demonstrated the depolarizing effect of procaine on the mitochondrial membrane by increasing the mitochondrial and intracellular $\mathrm{pH}$, in a dosedependent manner [87]. Yu et al. (2017) proved that procaine significantly increased neurotoxicity at high concentrations $(12,15$, and $20 \mathrm{mM})$, inducing mitochondrial dysfunction, overproduction of ROS, lipid peroxidation, DNA damage, and apoptosis, in human neuroblastoma cell line SH-SY5Y cells [88].

Recently, using a fluorescent assay with N-acetyl-3,7dihydroxyphenoxazine (Amplex Red), Ungurianu et al. (2020) showed the inhibitory effect of procaine and GH3 on rat liver mitochondria lipid peroxidation providing additional experimental data concerning their antioxidant action in these biological structures. At any of the employed concentrations $(0.5,1.0,2.0,5.0$, and $10 \mathrm{mM})$, procaine tended to inhibit lipid peroxidation at higher levels compared to GH3. The inhibitory effect was substantial at the lowest concentration $(0.5 \mathrm{mM}), 32 \%$ for $\mathrm{GH} 3$ and $42 \%$ for procaine, and increased in a dose-dependent manner. Both procaine and $\mathrm{GH} 3$ inhibited at $10 \mathrm{mM}$ more than $80 \%$ of the reactive peroxides production in isolated mitochondria fraction [29].

4.3. Cellular Antioxidant Systems-In Vivo Studies. A significant number of studies reported the beneficial effects of in vivo treatments with procaine and $\mathrm{GH} 3$ in animal models, by modulating the expression of antioxidant enzymes. Thus, chronic treatment with GH3 (20 mg/procaine/ $\mathrm{kg}$ body weight, three times a week, for nine weeks) modulated lipid peroxidation in homogenates from rat brain tissue as well as $\mathrm{O}_{2}{ }^{--}$generation, in correlation with an increase in SOD enzymatic activity [23]. Additionally, procaine and $\mathrm{GH} 3$ also induce a significant increase of catalase (CAT) activity in liver and kidney of young, adult, and old rats, and a decrease in the heart of old and adult female rats [89]. Previously, studies using fluorescence and electronic microscopy showed that GH3 treatment decreased lipofuscin (the aging pigment) accumulation in rat brain, testicles, liver, and heart $[90,91]$.

Procaine as well as procainamide is usually used for the therapy of cardiac arrhythmias. Recently, Qiang et al. (2019) investigated, in vitro and in vivo, the protective effect of novel 1,3,5-triazine-procaine derivatives against myocardial ischemia-reperfusion injury on the basis of various parameters, such as hemodynamic indices, myocardial enzymes, oxidative stress biomarkers: antioxidant enzymes (SOD, CAT, and glutathione peroxidase [GPx]), glutathione (GSH), hydroxyl radical and superoxide anion scavenging assays, as well as cardiac histopathological examination. Results showed an efficient reduction of ROS, as well as restored to normal levels of GSH and SOD, CAT, and GPx enzymatic activities in the triazine-procaine derivativestreated group, as compared to myocardial ischemiareperfusion group. Within this comprehensive experimental model, procaine-1,3,5-triazine derivatives showed significant cardioprotective action via inhibition of nuclear factor-kappa light chain enhancer of activated B cells (NF- $\kappa \mathrm{B})$ [28].

4.4. Lipoprotein Oxidation and Metabolism. Plasma lipoproteins are perfect biological "sensors" of oxidative stress in the arterial wall due to their close interactions with vascular endothelial cells and the high susceptibility of lipids to oxidative alterations [92]. Of particular interest is the impact of oxidative stress on plasma low-density lipoproteins (LDL), as oxidized LDL (oxLDL) are recognized to play a crucial role in promoting atherogenesis by several mechanisms involving their cytotoxicity on monocyte-derived macrophage cells, through reactive species generation and antioxidant failure $[93,94]$. Therefore, LDL are the most targeted by oxidative stress associated with metabolic imbalances such as hyperlipidemia, hyperglycemia, or insulin resistance. Increased LDL oxidation and development of a low-grade proinflammatory environment have been proposed to contribute to agedependent endothelial dysfunction [94].

Gradinaru et al. (2009) studied in vitro the effect of procaine and GH3 on LDL oxidation, by incubating native LDL isolated from human plasma with $0.1,0.5$, and $1 \mathrm{mM}$ procaine/GH3. The kinetic analysis of conjugated dienes formation during the $\mathrm{Cu}^{2+}$-induced oxidation of $\mathrm{LDL}$ revealed that $1 \mathrm{mM}$ procaine significantly inhibited LDL oxidation at 20 and 60 minutes after its inducement, whereas $1 \mathrm{mM}$ GH3 exerted a long-lasting antioxidant effect, with a significant inhibition even after 180 minutes [25].

Ungurianu et al. (2020), using a sensitive-fluorescent assay with Amplex Red, also pointed out, in human serum lipoprotein concentrates, a dose-dependent inhibitory action of procaine and $\mathrm{GH} 3$ on lipid peroxidation, significant at all tested concentrations $(0.5,1.0,2.0,5.0$, and $10 \mathrm{mM})$. GH3 showed a significantly higher lipid peroxidation inhibition compared to procaine. Additionally, the effect of $\mathrm{GH} 3$ and procaine treatment was examined on cell-mediated LDL oxidation induced in human-derived U937 cultured macrophages. Cellular oxidative stress was evaluated using the thiobarbituric acid reactive substances (TBARS) released in 
the incubation medium, as oxidative stress biomarker for the global measurement of lipid peroxidation end-products such as malondialdehyde (MDA) and 4-hydroxynonenal (4-HNE). At all the tested concentrations $(0.5,1.0$, and $2.0 \mathrm{mM}$ ), GH3 significantly decreased TBARS (\%), whereas the effect of procaine was lower, reaching only half of GH3 effect at $2 \mathrm{mM}$ [29].

Overall, procaine's significant antioxidant action demonstrated by in vitro and in vivo studies may contribute to its geroprotective effect, but the question is which are the molecular mechanisms for procaine's antioxidant effect? It could act as an inhibitor of the chain reactions generating the lipid peroxides, or/and as "scavenger" of the ROS. While procaine was more effective in protecting the cellular and mitochondrial membranes, GH3 was more efficient against serum lipoperoxidation. These outcomes could be explained through the different lipid or lipoprotein microenvironments present in these biological systems and/or through the different intrinsic antioxidant capacities or ROS scavenging actions of procaine and $\mathrm{GH} 3$, in counteracting or preventing lipid peroxidation [29].

The main limitation of these studies is that they present overall effects and did not investigate the specific molecular and cellular mechanisms involved, such as the modulation of signaling pathways which can result in enhancing cell antioxidant response. Therefore, further investigations are needed to establish the exact mechanisms of action of procaine and GH3.

Several experimental studies have highlighted the role of procaine as a modulator of lipid metabolism $[95,96]$. The lipid-lowering action of procaine was explained via a "statin-like" action exerted through the regulation of 3methylglutaryl-coenzyme A (HMG-CoA) reductase, the key enzyme in cholesterol biosynthesis [35]. The effect of procaine on steroidogenesis was reported in human H295R adrenal cells and in procaine-treated rats. This inhibitory activity was not observed in Leydig cells, suggesting that the effect could be specific to adrenocortical cells. Procaine did not affect either cyclic AMP- (cAMP-) dependent protein kinase activity, key proteins involved in mitochondrial cholesterol transport, side-chain cleavage enzymes, or enzymatic activities associated with the final stage of cholesterol biosynthesis. However, procaine reduced HMG-CoA reductase activity and specific mRNA expression dose-dependently. The modulatory effect of procaine on HMG-CoA reductase mRNA was also observed in the Hepa 1-6 mouse hepatoma cells stimulated by dibutyryl-cyclicAMP (dbcAMP) [35].

Procaine was also tested in vitro for its action as an inhibitor of the two enzymes involved in cholesterol esterification: acyl-CoA cholesterol acyltransferase (ACAT) and lecithincholesterol acyltransferase (LCAT) [97, 98]. Bell and Hubert (1981) used a microsomal fraction isolated from rabbit aorta, in which they monitored the incorporation of $\left[{ }^{14} \mathrm{C}\right]$-oleylSCoA in the form of $\left[{ }^{14} \mathrm{C}\right]$-cholesterol esters. The ACAT activity was inhibited depending on the concentration of anesthetic $(0.25-0.50 \mathrm{mM}$ procaine) in the reaction medium [97]. Another experiment was performed in vitro in human, rat, and dog plasma samples incubated with $1-5 \mathrm{mM}$ procaine, which significantly inhibited LCAT activity [98]. Some longitudinal and clinical studies carried out in elderly subjects with systemic atherosclerosis evidenced the lipidlowering and antioxidant actions of GH3 treatment $[24,30]$.

These results lead to a complex pharmacological profile of procaine, which includes the modulation of cholesterol metabolism at all levels, from genetic control of sterol biosynthesis to its esterification in plasma and tissues, with potential clinical applications in the treatment of hypercholesterolemia. Moreover, elevated glucocorticoid levels are associated with many pathologies, including age-related depression, hypertension, Alzheimer's disease (AD), or acquired immunodeficiency syndrome, cortisol biosynthesis reducing agents being a possible useful complementary therapy for all these conditions.

All these data may suggest that a combination of GH3 with lipid-lowering drugs could diminish the doses and the adverse effects of the classical treatment of hyperlipidemia.

\section{Cerebral Age-Related Pathology}

Similar to the structurally related cocaine, the effects of procaine go beyond its anesthetic actions, with some concerning the central nervous system (CNS). Several beneficial effects of procaine and GH3 were reported, such as ameliorating depression and cognitive abilities (conditioned behavior, memory) and increasing cerebral resistance to different aggressive actions (acute intoxication, hypoxia, and electric shock) [36, 37, 99-105].

Monoamine oxidases (MAOs), a class of enzymes involved in the metabolism of catecholamines and other biogenic amines, are increasingly recognized as major contributors to the generation of mitochondrial ROS. The bestknown and characterized MAOs are the endothelial and neuronal ones. However, the inducible isoforms which can be expressed in various tissues and organs have lately gained notoriety and stimulated interest in the extracerebral roles of these enzymes. For an overview of the complex roles of MAOs in age-associated diseases, the reader is referred to a recent review by Santin et al. (2021) [106]. It is well known that the expression of human MAOs and their abilities to produce ROS increase with age (4-fold MAO-B in neuronal tissue and 6-fold MAO-A in the heart) and are involved in the etiology of age-associated chronic pathologies: depressive disorders, Parkinsonism, cardiac diseases, and diabetes $[107,108]$.

In 1940, Philpot evidenced for the first time, using rat liver homogenate, procaine's inhibitory effect on the tyramine and adrenaline oxidation, at high concentrations (33 mM procaine) in the reaction mixture [109]. Further studies pointed out MAO inhibitory actions for both procaine and GH3 in brain, liver, and heart tissues from mice and rats $[110,111]$. The MAO B inhibitory action of procaine was reported following pharmacodynamics studies, and GH3 was included in the category of reversible and competitive inhibitors $[112,113]$. The inhibition of MAO activity by local anesthetics depends on both electrostatic and hydrophobic interactions between these drugs and enzyme-associated phospholipids or the hydrophobic regions of proteins [114]. MAO inhibitory effect was associated with the inhibition of 
lipid peroxidation in rat brain homogenates and mitochondrial fraction, pointing out that MAO activity could be inhibited through a limitation of free radical reactions [115].

Using rat pheochromocytoma PC12 cells, Lecanu et al. (2005) observed that procaine is a ligand of the sigma 1 receptor, a protein whose ligands have been shown to protect mitochondrial function and to exert antidepressant properties. Procaine also displayed strong neuroprotective properties against the amyloid peptide $\mathrm{A} \beta_{1-42}$ and preserved $\mathrm{A} \beta_{1 \text { - }}$ ${ }_{42}$-induced ATP depletion. Procaine inhibited the neurotoxic effect of glutamate on PC12 cells, suggesting that the reduction of glutamate-induced neurotoxicity may be the mechanism by which procaine exert its "anti-amyloid" effect [116]. Li et al. (2016) studied the effect of procaine treatment in a rat model of neuropathic pain. Procaine inhibited Janus kinase 2 (JAK2) and signal transducer and activator of transcription 3 (STAT3) expression, both mRNA and protein levels, indicating its cellular mechanism in attenuating neuropathic pain [117]. Recently, Wu et al. (2020) synthesized a series of procaine-imidazole derivatives with potent and selective MAO-B inhibitory activity, as well as in vivo anti-Parkinson effects using a 1-methyl-4-phenyl-1,2,3,6tetrahydropyridine (MPTP) model of Parkinson's disease. These procaine-based compounds determined a significant improvement of motor function in mice as revealed by motor behavioral assessment using the footprint and horizontal wire test and also improved the level of antioxidant enzymes in the striatum of animal brains [37].

Older studies regarding the effects of GH3 treatment on the function of CNS reported an improvement of cognitive function, better work capacity, increased resistance to stress and effort, decrease of depression symptoms, and an overall higher capacity of adapting to external stimuli. These data underlined that geriatric procaine-based products have minimum/short-lived side effects compared to classic CNStargeted medication, tolerated with difficulty by elderly with polypathology $[99,100,110,118,119]$. For decades, procaine infusions have been applied in patients with psychovegetative disturbances, mostly during neural therapy-a common complementary treatment approach using injections with short-acting local anesthetics to treat pain and chronic diseases. However, little is known about the underlying mechanisms and the domains of treatment response [102, 103].

Hahn-Godeffroy et al. (2019) studied, in 56 case-control patients, the effect of intravenous procaine (1-3 ampoules of $5 \mathrm{ml}$ of procaine $2 \%$ in $250 \mathrm{ml}$ sodium chloride per treatment setting) on the somatic and psycho-vegetative state of health. After 4 or 6 months, 75\% of patients showed an improvement in the 9 positive items, e.g., "hedonia," "joyness," or "improved sleep." $62.5 \%$ of patients reported a substantial attenuation in the 12 negative items, e.g., "stress reactions," "loss of energy," or "anxiety." All these changes were significant after 2,4 , and 6 months compared to the values at baseline, suggesting a long-lasting improvement of somatic and psycho-vegetative symptoms under the infusion of procaine alone, which modulates the activities of specific brain areas such as the limbic system [102].

Haller et al. (2018) performed, in 22 patients with multiple diagnoses, a qualitative analysis of self-reported outcomes following neural therapy injections with procaine. Patients experienced an emotional release and physical symptoms relief, consisting of improved mood, increased pain acceptance, and empowerment. Adverse events of neural therapy included pain at the injection site, vegetative complaints, and emotional turmoil that lasted for minutes or hours, with a maximum of two days [103]. Oettmeier et al. (2019) reported the clinical use of a highly-dosed infusion of procaine hydrochloride with sodium bicarbonate as an additive, for the treatment of different acute diseases, chronic pain, and inflammations [31].

$\mathrm{Xu}$ et al. (2016) explored the effects of daily use of GH3 tablets, for three months, on relieving mental symptoms and improving health-related quality of life among Chinese older adults. The randomized, placebo-controlled, doubleblinded study comprised 100 eligible participants, men and women between 50 and 89 years of age. GH3 treatment showed positive outcomes in supporting mental health and improving general health and well-being, while promoting the recovery of cognitive function among older adults. Average levels of low mood and anxiety concerns (evaluated with Self-Rating Depression and Anxiety Scales) were both reduced, and the prevalence rate of clinical anxiety was decreased [104].

\section{Negative Results Reported in Experimental and Clinical Studies}

The use of procaine for nonlocal-anesthetic purposes is highly controversial, especially when employed for its alleged "anti-aging effects" [15]. Different pharmaceutical preparations, including GH3, were widely promoted and commercially available "over the counter" in any country, especially via online marketing. Also, there are reports of studies which comparatively examined the effects of procaine (and GH3) and other anesthetics in different age-related maladies reported a lack of efficacy, as well the presence of toxicity or even severe side-effects [13, 14, 120-123].

Several experimental and clinical studies described significant neurologic alteration following procaine and $\mathrm{GH} 3$ treatment. In a review commissioned by the National Institute on Aging of the National Institutes of Health (USA), Ostfeld et al. (1977) evaluated scientific literature on the systemic use of procaine in the treatment of the aging process and the common chronic diseases, including data from 285 articles and books, describing the treatment in more than 100,000 patients. Except for a possible antidepressant effect, they found no convincing evidence that procaine or GH3 has any value in the treatment of aging-associated diseases in older patients [13] In a systematic review, Szatmari and Bereczki (2008) assessed independently the efficacy and adverse effects of procaine and GH3 treatment regarding cognitive function improvement in subjects with dementia from randomized, double-blind trials carried out before the 1990s. Pooling data from two studies showed a detrimental effect of procaine in terms of causing side effects. In patients with dementia, a single small study also suggested a negative effect, while two trials including healthy elderly individuals suggested a positive effect of procaine use on cognitive 
function. Authors concluded that the evidence for detrimental effects of procaine and its preparations is stronger than the data reporting its benefits in preventing and/or treating dementia or cognitive impairment [14].

Zaric and Pace (2009) searched the Cochrane Central Register of Controlled Trials for frequency of transient neurologic symptoms (TNS-painful condition that occurs in the immediate postoperative period) and neurologic complications after spinal anesthesia with lidocaine compared to other local anesthetics, including procaine. The risk of developing TNS after spinal anesthesia with lidocaine was significantly higher than when bupivacaine, prilocaine, or procaine were used [123]. Ghafari et al. (2012) evaluated, in a prospective, randomized, double-blind trial, comprising 110 patients (aged between 20 and 70 years), and the effect of lidocaine versus procaine on cognitive impairment manifested after coronary artery surgery. In the procaine group, the neurocognitive total score decreased significantly compared to the preoperative score and compared to the lidocaine group [122].

Takenami et al. (2012) aimed to compare the neurotoxicity of intrathecal procaine, bupivacaine, levobupivacaine, and ropivacaine in a rat spinal model. Although the four local anesthetics seemed to cause identical neurotoxic lesions commencing in the posterior root and extending to the posterior column by axonal degeneration, bupivacaine appeared to be the most neurotoxic of the four drugs, and the neurotoxicity at higher doses increased by administered volume with procaine $>$ levobupivacaine $>$ ropivacaine [121]. Yilbas et al. (2018) studied the effect of intra-articular procaine injection on knee articular cartilage and the synovium of SpragueDawley rats. Results showed no significant differences in inflammation (using a histological evaluation) between procaine and saline (control) groups at any duration of treatment (after 1, 2, 7, 14, and 21 days). No significant difference was detected in the percentage of apoptotic chondrocytes between groups at any of the time intervals [120].

\section{DNA Methylation and Tumorigenesis}

DNA methylation is an epigenetic modification involved in gene expression regulation. Age-associated alterations in DNA methylation are commonly grouped in the phenomenon known as "epigenetic drift," which is characterized by gradual extensive demethylation of genome and hypermethylation of a number of promoter-associated $5^{\prime}$-cytosinephosphate- guanine- $3^{\prime}(\mathrm{CpG})$ islands. For an overview on the reconfiguration of DNA methylation in aging the reader is referred to a recent review by Zampieri et al. (2015) [124]. Possible consequences are mutations and dysregulation of gene expression, which can either lead to cell death or cellular senescence or to malignant transformation of the cells, ultimately resulting in cancer [125]. DNA methyltransferases (DNMTs) are a family of enzymes that methylate DNA at the $\mathrm{C} 5$ position of cytosine followed by a guanine residue ( $\mathrm{CpG}$ dinucleotide). Reexpression of methylation silenced tumor suppressor genes by inhibiting the DNMTs (DNMT1, DNMT3A, and DNMT3B) has emerged as an effective strategy against cancer [126]. A large number of preclinical studies have shown that local anesthetics have a direct inhibitory effect on tumor activities, including cell survival, proliferation, migration, and invasiveness [41, 127, 128]. Recently, Moreira-Silva et al. (2020) cited procaine among the "repurposed drugs" which have demonstrated promising results as epigenetic inhibitor in in vitro tumorigenesis [129].

DNA hypermethylation and the consequent silencing of tumor suppressor genes are considered as a molecular hallmark of many kinds of cancers. Villar-Garea et al. (2003) demonstrated for the first time the role of procaine as a DNA demethylating agent in breast cancer cells, evidencing a $40 \%$ reduction in 5-methylcytosine $(5 \mathrm{mC})$ DNA content. Procaine had also the capacity to demethylate densely hypermethylated CpG islands, such as those located in the promoter region of the retinoic acid receptor (RAR) beta2 gene, restoring gene expression of epigenetically silenced genes. Finally, procaine also had growth-inhibitory effects in these cancer cells, causing mitotic arrest [38]. Gao et al. (2009) provided the first evidence that procaine is able to reactivate, in lung cancer cells, the Writ inhibitory factor-1 (WIF-1), which was silenced due to promoter hypermethylation [130].

Using hepatoma cells and nude mice bearing xenograft, Tada et al. (2007) revealed that procaine displayed both growth-inhibitory and demethylating effects on human hepatoma cells, both in vitro and in vivo. All the genes transcriptionally suppressed by DNA hypermethylation were demethylated and reactivated following procaine treatment. Morphological observations showed a significant reduction in tumor volume in vivo [131]. Castellano et al. (2008), who synthesized several analogues of procaine and tested their inhibiting activity against DNMT1, discovered a derivative able to induce a recognizable demethylation of chromosomal satellite repeats in HL60 human myeloid leukemia cells [132].

Another mechanism underlining procaine's anticancer activities is through direct interaction with DNA. In a multispectroscopic and molecular modelling study, Ali et al. (2018) used molecular docking on five different B-DNA structures (extracted from the Protein Data Bank) and showed that procaine binds to the adenine-thymine (AT) rich region of all five calf thymus B-DNA structures. Simultaneously, they found that procaine acts as an electron donor to DNA bases when testing the anticancer activity of procaine alone and in combination with doxorubicin in MCF-7 breast cancer cells [133].

Procaine also demonstrated nonepigenetic effects, such as the inhibition of cell proliferation and migration, and also enhancement of apoptosis in gastric cancer cells, osteosarcoma cells, colon cancer cells, mouse models of lung cancer, human leukemia cells, and human bladder cancer cells [134-139]. Borutinskaite et al. (2016) examined the effects of procaine as DNMT inhibitor on growth inhibition, apoptosis, and differentiation of human leukemia cells and showed an increase in the expression of molecules associated with differentiation, such as integrin CD11b, E-cadherin, granulocyte colony-stimulating factor (G-CSF), and apoptosis-peroxisome proliferator-activated receptor (PPAR) 
TABLE 1: Molecular and cellular effects of procaine reported within in vitro and in vivo studies, which support its antioxidant action.

\begin{tabular}{|c|c|c|c|c|}
\hline Preclinic model & Target & Concentrations/doses & Relevant finding & Reference \\
\hline $\begin{array}{l}\text { In vitro superoxide } \\
\left(\mathrm{O}_{2}^{-{ }^{-}}\right) \text {generation }\end{array}$ & $\begin{array}{l}\text { Nonenzymatic } \\
\text { system: [NADH- } \\
\text { PMS-NBT] }\end{array}$ & $\begin{array}{l}0.2 \text { to } 2.0 \mathrm{mM} \\
\text { procaine/GH3 }\end{array}$ & $\mathrm{O}_{2}^{--} \downarrow$ procaine; $\downarrow \downarrow \mathrm{GH} 3$ & $\begin{array}{c}\text { Rusu and } \\
\text { Lupeanu (1989) } \\
{[22]}\end{array}$ \\
\hline In vivo treatment & $\begin{array}{l}\text { Rat tissue samples } \\
\text { histopathological } \\
\text { analysis }\end{array}$ & $\begin{array}{l}20 \mathrm{mg} \text { procaine } / \mathrm{kg} \\
\text { body weight, } 3 \text { times/ } \\
\text { week } \times 9 \text { weeks }\end{array}$ & $\begin{array}{c}\mathrm{O}_{2}^{--} \downarrow \text { lipid peroxidation } \rightarrow \\
\text { (liver, brain, kidney) } \\
\downarrow \text { SOD activity (brain) } \\
\uparrow \text { CAT activity (liver, kidney) } \\
\text { Lipofuscin } \downarrow \\
\text { (brain, testicles, liver, heart) }\end{array}$ & $\begin{array}{l}\text { Rusu et al. (1992) } \\
\text { [23] } \\
\text { Lupeanu (1999) } \\
\text { [89] Radaceanu } \\
\text { et al. (1991) [90] }\end{array}$ \\
\hline In vitro sepsis & $\begin{array}{l}\text { Neutrophils + LPS, } \\
\text { triggered with fMLP }\end{array}$ & $4.0 \mathrm{mM}$ procaine & $\begin{array}{c}\downarrow 50 \% \text { LPS priming } \\
\downarrow \text { LPS-induced up-regulation, } \\
\text { cytochrome b558 }\end{array}$ & $\begin{array}{l}\text { Jinnouchi et al. } \\
\text { (2005) [64] }\end{array}$ \\
\hline $\begin{array}{l}\text { In vitro superoxide } \\
\left(\mathrm{O}_{2}^{--}\right) \text {generation }\end{array}$ & $\begin{array}{l}\text { Enzymatic system: } \\
\text { [xanthine - XO - } \\
\text { INT] }\end{array}$ & $\begin{array}{l}1.0 \text { to } 10.0 \mathrm{mM} \\
\text { procaine/GH3 }\end{array}$ & $\mathrm{O}_{2}^{\cdot-} \downarrow$ procaine; $\downarrow \downarrow \mathrm{GH} 3$ & $\begin{array}{l}\text { Gradinaru et al. } \\
\text { (2009) [25] }\end{array}$ \\
\hline $\begin{array}{l}\text { In vitro total } \\
\text { antioxidant capacity }\end{array}$ & $\begin{array}{c}\text { ABTS cation }+ \\
\text { different local } \\
\text { anesthetics }\end{array}$ & $10 \mathrm{mM}$ & $\begin{array}{l}\text { Scavenging }(\%) \text { : tetracaine }>\text { procaine }> \\
\text { lignocaine }>\text { benzocaine }(99 ; 38 ; 21 ; 20 \%)\end{array}$ & $\begin{array}{l}\text { Librowski and } \\
\text { Moniczewski } \\
\text { (2010) [27] }\end{array}$ \\
\hline In vitro ROS exposure & $\begin{array}{l}\text { Isolated rabbit aortic } \\
\text { rings }\end{array}$ & $\begin{array}{l}10^{-5} \mathrm{M} \text { to } 3 \times 10^{-3} \mathrm{M} \\
\text { procaine/lidocaine }\end{array}$ & Endothelium-dependent vasorelaxation $\uparrow \downarrow$ & $\begin{array}{l}\text { Lee et al. }(2010) \\
\qquad[26]\end{array}$ \\
\hline In vitro sepsis & $\begin{array}{l}\text { Bovine aortic } \\
\text { endothelial cells }+ \\
\text { IL-1 } \beta / \text { LPS }\end{array}$ & $10 \mathrm{mM}$ procaine & $\downarrow$ NO production & $\begin{array}{l}\text { Takaishi et al. } \\
\text { (2013) [65] }\end{array}$ \\
\hline \multirow[b]{2}{*}{$\begin{array}{l}\text { In vivo and in vitro } \\
\text { myocardial ischemia- } \\
\text { reperfusion injury }\end{array}$} & Rat tissue samples & $\begin{array}{l}\text { 1,3,5-triazine-procaine } \\
\text { derivatives }\end{array}$ & $\begin{array}{c}\text { Cardioprotective } \\
\downarrow \downarrow \text { ROS }\end{array}$ & \multirow[b]{2}{*}{$\begin{array}{l}\text { Qiang et al. (2019) } \\
\text { [28] }\end{array}$} \\
\hline & $\begin{array}{c}\text { RAW264.7 } \\
\text { macrophages } \\
\text { transfected with NF } \\
-\kappa \mathrm{B}+\text { LPS }\end{array}$ & $\begin{array}{l}5 \text { and } 10 \mathrm{mg} / \mathrm{mL} \text {, in } \mathrm{K}- \\
\mathrm{H} \text { buffer solution } \mathrm{x} \\
45 \mathrm{~min} \\
100 \mathrm{mM}\end{array}$ & $\begin{array}{c}\uparrow \mathrm{GSH}, \mathrm{SOD}, \mathrm{CAT} \text {, and GPx } \\
\downarrow \text { LOX-1 } \\
\text { Antiapoptotic } \\
\downarrow \text { Bax; } \uparrow \text { Bcl-2 } \\
\text { Anti-inflammatory } \\
\downarrow N F-\kappa \mathrm{B},\end{array}$ & \\
\hline In vitro ROS exposure & $\begin{array}{l}\text { Jurkat cells }+ \\
\text { CuOOH }\end{array}$ & $\begin{array}{c}2.5 \text { to } 10 \mathrm{mM} \\
\text { procaine } / \mathrm{GH} 3\end{array}$ & $\begin{array}{c}\text { Membrane lipoperoxides } \\
\downarrow \text { procaine; } \downarrow \downarrow \text { GH3 }\end{array}$ & $\begin{array}{l}\text { Ungurianu et al. } \\
\text { (2020) [29] }\end{array}$ \\
\hline $\begin{array}{l}\text { In vitro X-ray-DNA } \\
\text { damage in human } \\
\text { lymphocytes }\end{array}$ & $\begin{array}{l}\text { PBMCs, young, and } \\
\text { elderly subjects }\end{array}$ & $\begin{array}{l}0.25 \text { to } 10 \mathrm{mM} \\
\text { procaine/GH3 }\end{array}$ & $\begin{array}{c}\text { Radioprotective }(0.25 \text { to } 1 \mathrm{mM}) \\
\text { GH3 } \downarrow \text { DNA damage, young } \\
\text { Procaine } \downarrow \text { endogenous DNA } \\
\text { strand breaks, aged } \\
\text { Genotoxic ( } 3 \text { to } 10 \mathrm{mM})\end{array}$ & $\begin{array}{l}\text { Ungurianu et al. } \\
\text { (2020) [29] }\end{array}$ \\
\hline
\end{tabular}

ABTS: 2,2' -Azino-bis (3-ethylbenzothiazoline-6-sulfonic acid) diammonium salt; Bcl-2: B-cell lymphoma 2; Bax: Bcl-2-associated X protein; CAT: catalase; $\mathrm{CuOOH}$ : cumene hydroperoxide; fMLP: N-formyl-methionyl-leucyl phenylalanine chemotactic peptide; GH3: Gerovital H3; GPx: glutathione peroxidase; GSH: reduced glutathione; IL-1 $\beta$ : interleukin-1 beta; INT: 2-(4-iodophenyl)-3-(4-nitrophenol)-5-phenyltetrazolium chloride; LOX-1: lectin-like oxidized low-density lipoprotein receptor-1; LPS: lipopolysaccharide; NADH: reduced nicotinamide adenine dinucleotide; NBT: nitroblue tetrazolium; NF- $\kappa$ B: nuclear factor kappa light chain enhancer of activated B cells; NO: nitric oxide; PBMCs: peripheral blood mononuclear cells; PMS: phenazine methosulfate; ROS: reactive oxygen species; SOD: $\mathrm{Cu} / \mathrm{Zn}$-superoxide dismutase; $\mathrm{XO}$ : xanthine oxidase.

gamma. Moreover, procaine enhanced certain gene transcription activation via chromatin remodeling - the changes in histone $\mathrm{H} 3 \mathrm{~K} 4(\mathrm{Me}) 3$ and $\mathrm{H} 3 \mathrm{~K} 9 \mathrm{Ac} / \mathrm{S} 10 \mathrm{P}$ modifications were detected [138]. Sun et al. (2012) proved that procaine might be used as a potential agent for bladder cancer treatment as it inhibited the proliferation of T24 and 5637 human bladder cancer cells by inducing their apoptosis. The mechanism studies reveal that procaine could induce demethylation of apoptotic peptidase activating factor 1 (APAF1) gene in T24 or 5637 cells, subsequently activating caspase-3/9. It was also shown that the serum soluble fas ligand (sFasL) was activated, and the expression of matrix metallopeptidase 9 (MMP-9) was downregulated [139]. The common mechanism by which procaine inhibited cancer cell proliferation and migration was the inactivation of the extracellular signal-regulated kinase (ERK)/mitogen-activated protein kinase (MAPK)/focal nuclear adhesion kinase (FAK) and protein kinase $B$ (AKT)/extracellular signal-regulated kinase (ERK) pathways $[134,135]$. In a recent study, Fan et al. (2021) identified a novel mechanism through which procaine can impair the survival and self-renewal of the malignant glioblastoma stem cells, suggesting that local anesthetics may weaken zinc finger Asp-HisHis-Cys-type palmitoyltransferase 15 (ZDHHC15) transcripts and decrease glycoprotein 130 (GP130) palmitoylation levels 
TABLE 2: Molecular and cellular effects of procaine on mitochondria function, reported within in vitro studies.

\begin{tabular}{|c|c|c|c|c|}
\hline Preclinic model & Target & Concentrations/doses & Relevant finding & Reference \\
\hline In vitro & Rat liver mitochondria & $\begin{array}{c}0.5 \text { to } 10 \mathrm{mM} \\
\text { procaine/GH3 }\end{array}$ & $\begin{array}{c}\text { Procaine }(1 \mathrm{mM}) \uparrow \text { basal state, } \\
\text { respiration before ADP addition } \\
\text { Procaine }(>10 \mathrm{mM}) \downarrow 2,4 \text {-DNP, } \\
\text { oxidative phosphorylation } \\
\text { Lipid peroxidation } \\
\downarrow \downarrow \text { procaine } \downarrow \mathrm{GH} 3\end{array}$ & $\begin{array}{c}\text { Tarba and } \\
\text { Cracium, } 1990 \\
{[33]} \\
\text { Rusu (1990) [84] } \\
\text { Borsa et al. (2002) } \\
\text { [115] } \\
\text { Ungurianu et al. } \\
\text { (2020) [29] }\end{array}$ \\
\hline $\begin{array}{l}\text { In vitro cisplatin- } \\
\text { induced nephrotoxicity }\end{array}$ & Rat renal cortical slices & $2 \mathrm{mM}$ procaine & $\begin{array}{c}\downarrow \text { mitochondrial injury } \\
\downarrow \text { cellular damage } \\
\downarrow \text { lipid peroxidation }\end{array}$ & $\begin{array}{c}\text { Zhang and } \\
\text { Lindup (1994) } \\
{[86]}\end{array}$ \\
\hline In vitro sepsis & $\begin{array}{l}\text { Human vascular } \\
\text { endothelial cells + LPS }\end{array}$ & $\begin{array}{l}0.01 \text { to } 1.0 \mathrm{mM} \\
\text { procaine }\end{array}$ & $\begin{array}{c}\rightarrow \text { cell injury } \\
\downarrow \text { mitoKATP activation }\end{array}$ & $\begin{array}{l}\text { de Klaver et al. } \\
\text { (2006) [83] }\end{array}$ \\
\hline In vitro & $\begin{array}{l}\text { Rat dorsal root } \\
\text { ganglion neurons }\end{array}$ & $\begin{array}{l}1,5 \text {, and } 10 \mathrm{mM} \\
\text { procaine }\end{array}$ & $\begin{array}{l}\uparrow \text { depolarization of the mitochondrial } \\
\text { membrane potential }(\Delta \Psi \mathrm{m}) \uparrow[\mathrm{pH}] \mathrm{m}\end{array}$ & $\begin{array}{l}\text { Onizuka et al. } \\
\text { (2010) [87] }\end{array}$ \\
\hline In vitro neuroblastoma & $\begin{array}{l}\text { Human cell line SH- } \\
\text { SY5Y }\end{array}$ & $\begin{array}{l}12,15 \text {, and } 20 \mathrm{mM} \\
\text { procaine }\end{array}$ & $\begin{array}{c}\uparrow \text { neurotoxicity, } \uparrow \text { mitochondrial } \\
\text { dysfunction, } \uparrow \text { ROS } \\
\uparrow \text { lipid peroxidation } \\
\uparrow \text { DNA damage and apoptosis }\end{array}$ & $\begin{array}{l}\text { Yu et al. (2017) } \\
{[88]}\end{array}$ \\
\hline
\end{tabular}

2,4-DNP: 2,4-dinitrophenol; GH3: Gerovital H3; mitoKATP: mitochondrial ATP-sensitive potassium channel; ROS: reactive oxygen species.

and membrane localization, thus, inhibiting the activation of interleukin-1 (IL-6)/signal transducer and activator of transcription 3 (STAT3) signaling [41].

As to procaine's effects in normal cells, Schumann et al. (2020) characterized the action of procaine and S-adenosylL-homocysteine (SAH) as demethylating agents, on the expression of genes related to the epigenetic machinery, including the DNMTs and on DNA methylation levels in bovine skin fibroblasts. Global DNA methylation levels were significantly lower in cells that were cultivated in medium containing both compounds versus control cells, and gene expression of DNMT1, DNMT3A, and DNMT3B decreased significantly in cells cultivated with $\mathrm{SAH}+$ procaine $(1 \mathrm{mM})$. Moreover, a significant decrease in DNMT3B transcript levels was found in cells cultivated with procaine. Higher levels of the ten-eleven translocation enzyme-3 (TET3) dioxygenase, involved in the epigenetic machinery, were also found in cells cultivated with procaine and $\mathrm{SAH}+$ procaine, compared with the control [40].

Using a mouse behavioral sensitization model in which animals were subjected to an acute treatment with procaine for seven days, Anier et al. (2018) found that procaine caused a decrease on the DNMT3A mRNA levels in peripheral blood cells (PBCs), suggesting that the inhibition of voltage-gated sodium channels may be the mechanism that alters DNMT expression in PBCs [39].

\section{Procaine Effects on Lifespan}

The studies researching procaine's influence on lifespan are scarce. An experimental study conducted by Aslan et al. (1965) on 1840 rats pointed out $18-21 \%$ longer lifespan in treated animals than that of controls injected with saline solution [140]. Another investigation on lifespan was conducted on 3680 animals from 5 successive generations. The outcome supported that GH3 administered since early ages induced a lifespan extension both in the treated animals, as well as in the first generation of not-treated offspring [141]. In Drosophila melanogaster grown on nutritive medium enriched with $\mathrm{GH} 3$ was also found out a $22.7 \%$ lifespan extension, compared with controls [142]. Unfortunately, there are no recent studies regarding the effects of procaine and/or GH3 on lifespan.

\section{Conclusions and Perspectives}

The analysis of older and more recent (between 1990 and 2020) literature data reveals the diversity of procaine's effects at cellular and molecular levels, in preclinical studies and clinical settings.

Summarizing its cellular actions, procaine is able to bind to membrane constituents and interact with a series of ion channels exerting its anesthetic action [42, 143] and also has a significant influence on oxidative stress response, on the modulation of critical metabolic pathways, as well as on epigenetic regulation.

The antioxidant action of procaine is supported by in vitro and in vivo experimental studies regarding the inhibition of ROS generation and lipid peroxidation, in enzymatic [25] and nonenzymatic systems [23, 27], associated with a modulating effect on antioxidant enzymes [23, 28, 89]. Several studies confirm its involvement in mitigating cellular and systemic oxidative stress, acting on the main targets of aging and age-related diseases: cell membranes [22, 24], lipoproteins [25, 29], mitochondria [29, 37, 86], and DNA [29]. Procaine reaffirmed its antioxidant and cytoprotective actions in experimental models of myocardial ischemia/reperfusion injury [28, 83], endothelial-dependent vasorelaxation [26], inflammation [65], sepsis [64], ionizing irradiation [29], and intoxication [85, 86] (Table 1). 
TABLE 3: Molecular and cellular effects of procaine on lipoprotein oxidation and metabolism, reported within in vitro and in vivo studies, which support its antiatherogenic action.

\begin{tabular}{|c|c|c|c|c|}
\hline Preclinic model & Target & Concentrations/doses & Relevant finding & Reference \\
\hline $\begin{array}{l}\text { In vitro and in vivo } \\
\text { treatment }\end{array}$ & $\begin{array}{l}\text { Human H295R adrenal cells, } \\
\text { Hepa 1-6 mouse hepatoma cells }\end{array}$ & $\begin{array}{l}0.1,1,10 \text {, and } 100 \mu \mathrm{M} \\
\text { procaine, for } 48 \mathrm{~h} \\
25-100 \mathrm{mg} \text { procaine/kg } \\
\text { body weight, } 8 \text { days }\end{array}$ & $\begin{array}{c}\downarrow \text { steroidogenesis } \\
\downarrow \text { HMG-CoA reductase } \\
\text { activity } \\
\downarrow \text { mRNA expression } \\
\downarrow \text { serum corticosterone }\end{array}$ & Xu et al. (2003) [35] \\
\hline In vitro treatment & $\begin{array}{l}\text { Human, rat, dog plasma } \\
\text { Rabbit aorta microsomes }\end{array}$ & $\begin{array}{c}1-5 \mathrm{mM} \text { procaine } \\
0.25-0.50 \mathrm{mM} \text { procaine }\end{array}$ & $\begin{array}{c}\downarrow \text { plasma LCAT } \\
\downarrow \text { ACAT }\end{array}$ & $\begin{array}{c}\text { Bell and Hubert (1980) } \\
\text { [97] } \\
\text { Bell (1981) [98] }\end{array}$ \\
\hline In vitro LDL oxidation & Human plasma $\mathrm{LDL}+\mathrm{Cu}^{2+}$ & $\begin{array}{c}0.1-1.0 \mathrm{mM} \\
\text { procaine/GH3 }\end{array}$ & $\begin{array}{l}\text { Conjugated dienes } \\
\downarrow \text { procaine; } \downarrow \downarrow \text { GH3 }\end{array}$ & $\begin{array}{c}\text { Gradinaru et al. (2009) } \\
\text { [25] }\end{array}$ \\
\hline In vitro LDL oxidation & $\begin{array}{l}\text { U937 macrophages }+ \text { human } \\
\text { plasma } \mathrm{LDL}+\mathrm{Cu}^{2+}\end{array}$ & $0.5-2.0 \mathrm{mM}$ & $\begin{array}{c}\text { TBARS } \\
\downarrow \text { procaine; } \downarrow \downarrow \text { GH3 }\end{array}$ & $\begin{array}{c}\text { Ungurianu et al. (2020) } \\
\text { [29] }\end{array}$ \\
\hline $\begin{array}{l}\text { In vitro lipoprotein } \\
\text { oxidation }\end{array}$ & $\begin{array}{l}\text { Human serum lipoprotein } \\
\text { concentrates }\end{array}$ & $\begin{array}{c}0.5 \text { to } 10 \mathrm{mM} \\
\text { procaine } / \mathrm{GH} 3\end{array}$ & $\begin{array}{l}\text { Lipid peroxidation: } \\
\downarrow \text { procaine; } \downarrow \downarrow \text { GH3 }\end{array}$ & $\begin{array}{c}\text { Ungurianu et al. (2020) } \\
\text { [29] }\end{array}$ \\
\hline
\end{tabular}

ACAT: acyl-CoA cholesterol acyltransferase; GH3: Gerovital H3; HMG-CoA: 3-methylglutaryl-coenzyme A; LCAT: lecithin-cholesterol acyltransferase; LDL: low-density lipoproteins; TBARS: thiobarbituric acid reactive substances.

TABLE 4: Molecular and cellular effects of procaine reported within in vitro and in vivo studies, which support its neuroprotective actions.

\begin{tabular}{|c|c|c|c|c|}
\hline Preclinic model & Target & Concentrations/doses & Relevant finding & Reference \\
\hline In vivo treatment & $\begin{array}{l}\text { Rat brain and liver } \\
\text { mitochondria }\end{array}$ & $\begin{array}{c}60 \mathrm{mg} \text { procaine } / \mathrm{kg} \text { body weight, } 5 \\
\text { times/week } \times 4 \text { weeks }\end{array}$ & $\begin{array}{c}\text { MAO activity: } \\
\downarrow \text { procaine; } \downarrow \downarrow \text { GH3 }\end{array}$ & $\begin{array}{l}\text { Borsa et al. } \\
(2002) \text { [115] }\end{array}$ \\
\hline $\begin{array}{l}\text { In vitro } \beta \text {-amyloid-induced } \\
\text { neurotoxicity }\end{array}$ & $\begin{array}{l}\text { Rat pheochromocytoma } \\
\text { PC12 cells }\end{array}$ & 1,10 , and $100 \mu \mathrm{M}$ procaine & $\begin{array}{c}\downarrow \text { amyloid peptide } \\
\text { A } \beta 1-42 \\
\downarrow \text { amyloid -induced } \\
\text { ATP depletion } \\
\downarrow \text { glutamate } \\
\text { neurotoxic effect }\end{array}$ & $\begin{array}{l}\text { Lecanu et al. } \\
(2005)[116]\end{array}$ \\
\hline In vivo neuropathic pain & $\begin{array}{c}\text { Rat tissue samples of L4-L6 } \\
\text { spinal dorsal horn } \\
\text { Behavior tests }\end{array}$ & $\begin{array}{l}2 \% \text { procaine intrathecal injection in } \\
\text { DMSO }(10 \mu \mathrm{L} / \mathrm{kg})\end{array}$ & $\begin{array}{c}\downarrow \text { JAK2 } \downarrow \text { STAT3 } \\
\text { (mRNA+protein) } \\
\downarrow \text { pain behavior }\end{array}$ & $\begin{array}{l}\text { Li et al. (2016) } \\
\text { [117] }\end{array}$ \\
\hline $\begin{array}{l}\text { In vivo MPTP-induced } \\
\text { Parkinson's disease }\end{array}$ & $\begin{array}{c}\text { Rat liver mitochondria } \\
\text { Mouse brain homogenate } \\
\text { Behavior tests }\end{array}$ & $\begin{array}{l}\text { Procaine-imidazole derivatives } \\
25,50 \text {, and } 100 \mathrm{mg} / \mathrm{kg} \text { body weight, } \\
3 \text { days }\end{array}$ & $\begin{array}{c}\downarrow \text { MAO-B } \\
\uparrow \text { striatum antioxidant } \\
\text { enzymes } \\
\uparrow \text { motor function }\end{array}$ & $\begin{array}{l}\text { Wu et al. (2020) } \\
\text { [37] }\end{array}$ \\
\hline
\end{tabular}

GH3: Gerovital H3; DMSO: dimethyl sulfoxide; JAK2: Janus kinase 2; MAO: monoamine oxidase; MPTP: 1-methyl-4-phenyl-1,2,3,6-tetrahydropyridine; STAT3: signal transducer and activator of transcription 3.

Like many pharmacologic active molecules, procaine exhibits a multimodal dose response. In low concentrations $(\leq 1 \mathrm{mM})$, protective effects were reported regarding mitochondrial function, lipid peroxidation, and DNA damage, whereas high concentrations $(>10 \mathrm{mM})$ induced membrane rigidity, acceleration of free radical reactions, genotoxicity, neurotoxicity, mitochondrial dysfunction, and apoptosis [29, 33, 87, 88] (Table 2).

Procaine might exert its actions regarding the atherogenesis process by modulating lipoprotein metabolism, as an inhibitor of the key enzymes involved in cholesterol biosynthesis and esterification: HMG-CoA reductase, ACAT, and LCAT $[35,97,98]$, and via its antioxidant mechanisms, reducing the oxidative stress exerted on the $\operatorname{LDL}[25,29]$ (Table 3).

Numerous beneficial actions were reported for procaine concerning the CNS, beyond its anesthetic effect. Experimen- tal studies highlighted neuroprotective, antidepressant, and "anti-amyloid" actions [116], along inhibition of JAK2 and STAT3 expression in neuropathic pain models [117]. The inhibitory effect on MAO-B of procaine-derivatives, as well as the in vivo anti-Parkinson effect, was associated with lower levels of mitochondrial lipid peroxidation and improved levels of antioxidant enzymes in the striatum [37] (Table 4).

Various recent clinical studies pointed out the functional improvement of somatic and psycho-vegetative symptoms during neural therapy with procaine $[102,103]$. GH3 treatment shows positive effects in supporting mental health and improving general health and well-being, while promoting the recovery of cognitive function among older adults [104].

Procaine could be considered as a reference substance for DNA-demethylation and tumor-suppressive effects, although these interventions may only be detectable in specific types of cancer due to differential methylation profiles [144]. 
TABLE 5: Molecular and cellular effects of procaine as DNA demethylation and tumor-suppressive agent, reported within in vitro studies.

\begin{tabular}{|c|c|c|c|c|}
\hline Preclinic model & Target & Concentrations/doses & Relevant finding & Reference \\
\hline Breast cancer & Human MCF-7 cell line & $0.005-0.5 \mathrm{mM}$ procaine, $72 \mathrm{~h}$ & $\begin{array}{c}\downarrow 40 \% \text { DNA } 5 \mathrm{mC} \\
\downarrow R A R \beta 2 \text { gene CpG islands } \\
\uparrow \text { mitotic arrest }\end{array}$ & $\begin{array}{c}\text { Villar-Garea } \\
\text { et al. (2003) } \\
{[38]}\end{array}$ \\
\hline $\begin{array}{l}\text { Lung and colon } \\
\text { cancer }\end{array}$ & $\begin{array}{c}\text { Human H460, A549, and } \\
\text { HCT116 cells }\end{array}$ & $2 \mathrm{mM}$ procaine & $\uparrow$ silenced WIF-1 & $\begin{array}{l}\text { Gao et al. } \\
(2009) \text { [130] }\end{array}$ \\
\hline $\begin{array}{l}\text { Hepatocellular } \\
\text { carcinoma }\end{array}$ & $\begin{array}{l}\text { Human hepatoma cells and } \\
\text { nude mice bearing xenograft }\end{array}$ & $1 \mathrm{mM}$ procaine, 5 days & $\begin{array}{l}\uparrow \text { mitotic arrest } \\
\downarrow \text { CpG islands } \\
\downarrow \text { tumor volume }\end{array}$ & $\begin{array}{l}\text { Tada et al. } \\
(2007)[131]\end{array}$ \\
\hline Leukemia & Human myeloid HL60 cells & $\begin{array}{l}\text { Procaine analogues } \\
0.5 \mathrm{mM}, 72 \mathrm{~h}\end{array}$ & $\begin{array}{c}\downarrow \text { DNMT1 } \\
\downarrow \text { CpG islands }\end{array}$ & $\begin{array}{c}\text { Castellano } \\
\text { et al. (2008) } \\
{[132]}\end{array}$ \\
\hline Bladder cancer & Human T24 and 5637 cells & $5-10 \mu \mathrm{M}$ procaine & $\begin{array}{c}\downarrow \text { proliferation } \uparrow \text { apoptosis } \\
\leftrightarrow \text { APAF1 gene } \\
\text { demethylation } \\
\uparrow \text { caspase-3/9; } \uparrow \text { sFasL; } \downarrow \\
\text { MMP-9 }\end{array}$ & $\begin{array}{l}\text { Sun et al. } \\
(2012) \text { [139] }\end{array}$ \\
\hline Breast cancer & $\begin{array}{c}\text { Human BT-20 (ER-negative) } \\
\text { and MCF-7 (ER-positive) } \\
\text { cell lines }\end{array}$ & $\begin{array}{l}\text { Procaine and lidocaine, } 0.01 ; 0.1 \text {, } \\
\text { and } 1 \mathrm{mM}, 72 \text { and } 96 \mathrm{~h}\end{array}$ & $\begin{array}{c}\uparrow \text { apoptosis } \\
\downarrow \text { DNA } 5 \mathrm{mC}\end{array}$ & $\begin{array}{l}\text { Lirk et al. } \\
(2012) \text { [144] }\end{array}$ \\
\hline Lung cancer & $\begin{array}{c}\text { Mouse lung cancer with } \\
\text { A549 and NCI-H1975 } \\
\text { xenograft } \\
\text { Human nonsmall cell lung } \\
\text { cancer A549 and NCI-H1975 } \\
\text { cell lines }\end{array}$ & $50 \mathrm{mg}$ procaine $/ \mathrm{kg}$ body weight $\times 3$ weeks & $\begin{array}{l}\downarrow \text { cell proliferation } \\
\downarrow \text { EGFR mRNA }\end{array}$ & $\begin{array}{c}\text { Ma et al. } \\
(2016) \text { [137] }\end{array}$ \\
\hline Leukemia & Human NB4 cells & 3-5 $\mu \mathrm{M}$ procaine & $\begin{array}{c}\uparrow \mathrm{CD} 1 \mathrm{~b}, \mathrm{~b} \text {-cadherin, G-CSF } \\
\uparrow \mathrm{PPAR} \text { gamma } \\
\leftrightarrow \text { chromatin } \\
\text { remodeling-histone } \\
\mathrm{H} 3 \mathrm{~K} 4(\mathrm{Me}) 3 \text { and } \\
\mathrm{H} 3 \mathrm{~K} 9 \mathrm{Ac} / \mathrm{S} 10 \mathrm{P}\end{array}$ & $\begin{array}{c}\text { Borutinskaite } \\
\text { et al. (2016) } \\
{[138]}\end{array}$ \\
\hline Osteosarcoma & Human MG63 cells & $2 \mu \mathrm{M}$ procaine & $\begin{array}{c}\downarrow \text { proliferation and migration } \\
\uparrow \text { apoptosis } \\
\text { miR-133b upregulation } \\
\text { AKT/ERK inactivation }\end{array}$ & $\begin{array}{l}\text { Ying et al. } \\
2017[135]\end{array}$ \\
\hline Colon cancer & Human HCT11 cells & $\begin{array}{c}0.5,1,1.5, \text { and } 2 \mu \mathrm{M} \text { procaine } \\
3 \mu \mathrm{M} \text { procaine }+ \text { carboplatin } \\
5 \mu \mathrm{M} \text { procaine }\end{array}$ & $\begin{array}{c}\downarrow \text { proliferation and migration } \\
\uparrow \text { apoptosis } \\
\uparrow \text { RhoA expression } \\
\uparrow \text { DNA fragmentation } \\
\downarrow \text { DNA 5mC }\end{array}$ & $\begin{array}{c}\text { Li et al. (2018) } \\
\text { [136] } \\
\text { Sabit et al. } \\
(2016)[145]\end{array}$ \\
\hline $\begin{array}{l}\text { Mouse behavioral } \\
\text { sensitization } \\
\text { model }\end{array}$ & Peripheral blood cells & $1-10 \mu \mathrm{M}$ procaine & $\downarrow$ DNMT3A mRNA & $\begin{array}{l}\text { Anier et al. } \\
(2018)[39]\end{array}$ \\
\hline Gastric cancer & $\begin{array}{l}\text { Human SGC-7901 and GES- } \\
1 \text { cell lines }\end{array}$ & $1-5 \mu \mathrm{M}$ procaine & $\begin{array}{c}\downarrow \text { DNMT1/DNMT3A activity } \\
\downarrow \text { proliferation } \\
\uparrow \text { apoptosis } \\
\text { CDKN2A and RAR } \\
\text { upregulation }\end{array}$ & $\begin{array}{l}\text { Li et al. (2018) } \\
\text { [136] }\end{array}$ \\
\hline $\begin{array}{l}\text { Molecular } \\
\text { docking on B- } \\
\text { DNA structures }\end{array}$ & Calf thymus & $5-35 \mu \mathrm{M}$ procaine & $\begin{array}{c}\leftrightarrow \text { binding to AT rich regions } \\
\rightarrow \text { electron donor to DNA } \\
\text { bases }\end{array}$ & $\begin{array}{c}\text { Ali et al. } \\
(2018)[133]\end{array}$ \\
\hline Breast cancer & Human MCF-7 cell line & $5 \mu \mathrm{M}$ procaine & $\rightarrow$ anticancer activity & \\
\hline Normal cells & Bovine skin fibroblasts & Procaine + SAH (1 mM) & $\begin{array}{c}\downarrow \text { DNMT1, DNMT3A, } \\
\text { DNMT3B } \\
\downarrow \text { DNMT3B (procaine) } \\
\uparrow \text { TET3 dioxygenase }\end{array}$ & $\begin{array}{c}\text { Schumann } \\
\text { et al. (2020) } \\
{[40]}\end{array}$ \\
\hline
\end{tabular}


TABLE 5: Continued.

\begin{tabular}{|c|c|c|c|c|}
\hline Preclinic model & Target & Concentrations/doses & Relevant finding & Reference \\
\hline Brain cancer & $\begin{array}{c}\text { Human glioblastoma stem } \\
\text { cells }\end{array}$ & 5,10 , and $20 \mu \mathrm{M}$ procaine & $\begin{array}{c}\downarrow \text { survival and self-renewal } \\
\downarrow \text { ZDHHC15 transcripts } \\
\downarrow \text { GP130 palmitoylation } \\
\downarrow \text { activation of IL-6/STAT3 }\end{array}$ & $\begin{array}{l}\text { Fan et al. } \\
(2021)[41]\end{array}$ \\
\hline
\end{tabular}

5mC: 5-methylcytosine; AKT: protein kinase B; APAF1: apoptotic peptidase activating factor 1; AT: adenine-thymine; CDKN2A: cyclin dependent kinase inhibitor 2A; CpG: $5^{\prime}$-cytosine-phosphate-guanine-3'; DNMT: DNA methyltransferase; EGFR: epidermal growth factor receptor; ERK: extracellular signalregulated kinase; ER: oestrogen receptor; G-CSF: granulocyte colony-stimulating factor; GP130: glycoprotein 130; H3K4 (Me)3: tri-methylation at the 4th lysine residue of the histone $\mathrm{H} 3$ protein; H3K9Ac/S10P: phospho-acetylated histone H3; miR: microRNA; MMP-9: matrix metallopeptidase 9; PPAR: peroxisome proliferator-activated receptor; RAR: retinoic acid receptor; RhoA: Ras homolog family member A; SAH: S-adenosyl-L-homocysteine; sFasL: serum soluble fas ligand; STAT3: signal transducer and activator of transcription 3; TET3: translocation enzyme-3; WIF-1: Writ inhibitory factor-1; ZDHHC15: zinc finger Asp-His-His-Cys-type palmitoyltransferase 15.

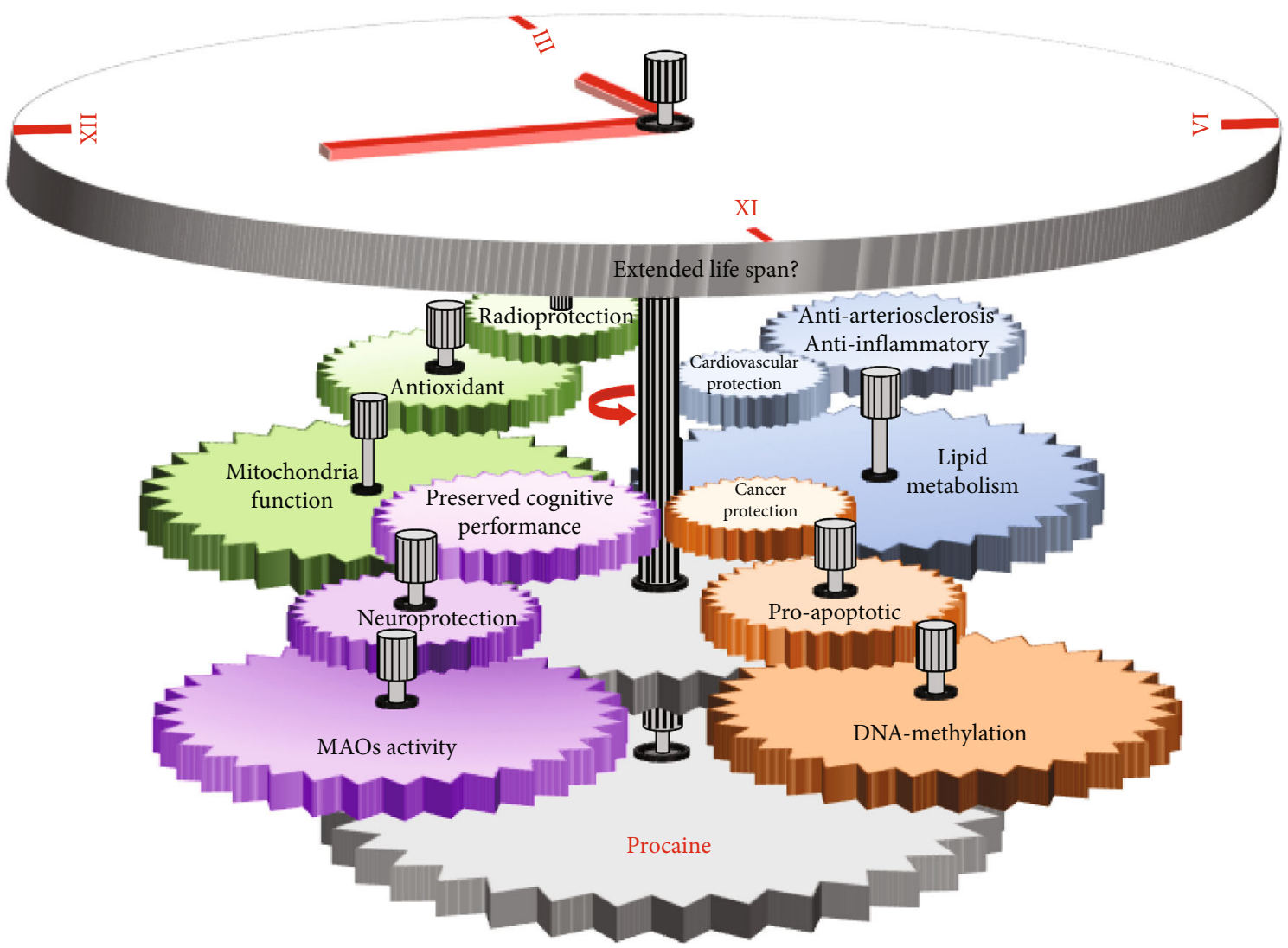

FIGURE 2: New biological and pharmacological effects of procaine-demonstrated within novel experimental approaches-which could acknowledge its consideration as a potential geroprotector candidate.

Recently, procaine was included among the potential "repurposed drugs" with promising results as an epigenetic modulator [129]. An important number of preclinical studies demonstrated the role of procaine as DNA-demethylating agent through the inhibition of DNA methyltransferases in normal $[39,139]$ and cancer cells [132], or through direct interaction with DNA [133]. In a variety of cancer cells, procaine is able to reactivate tumor suppressor genes, such as WIF-1 [130], and impair the survival and self-renewal of the malignant cells by inhibiting the activation of IL6/STAT3 signaling [41]. Procaine also inhibits cancer cell proliferation and migration, enhancing apoptosis, through the inactivation of the ERK/MAPK/FAK and AKT/ERK pathways [134-139, 145] (Table 5).
In conclusion, beyond its well-known anesthetic action, procaine displays a variety of biological and pharmacological effects, functioning as an antioxidant, anti-inflammatory, cardioprotective, neuroprotective, radioprotective, cytoprotective, and demethylating agent. The beneficial effects on cellular functions and metabolism could designate procaine as a valuable candidate for the Geroprotectors (http:// geroprotectors.org) database (Figure 2).

Future research approaches are likely to evaluate procaine's effects in animal and cellular experimental models, focusing on lifespan assessment, autophagy and proteasome regulation, replicative senescence-telomere length and telomerase activity, cell cycle regulation including aging-related pathways such as insulin/insulin-like growth factor 1 (IGF- 
1)/phosphatidylinositol-3 kinase (PI3K)/AKT (Protein Kinase $\mathrm{B}$ ) and the Forkhead box $\mathrm{O}$ (FOXO) transcription factors (FOXOs), as well as the energy sensing molecular apparatus comprising the mammalian target of rapamycin (mTOR), the adenosine monophosphate-activated protein kinase (AMPK), and the sirtuins. Only after extended investigation with novel experimental approaches, we will be able to fully understand the modulatory action of procaine in the mechanisms of aging and the etiology of chronic degenerative maladies. Following the in-depth comprehension of the fascinating multiples facets of procaine, a judicious use of procaine-based drugs could be employed in the prophylaxis and treatment of different metabolic and degenerative disorders commonly encountered in elderly patients, but which nowadays seem to affect younger and younger individuals.

\section{Data Availability}

Review article based on PubMed database.

\section{Conflicts of Interest}

The authors declare that there is no conflict of interest regarding the publication of this paper.

\section{References}

[1] P. Dosch and M. Dosch, Manual of neural therapy according to Huneke, Thieme, Stuttgart, Germany, 2007.

[2] E. J. Moynahan, "Treatment of acute sprains by procaine infiltration (Leriche's method)," British Medical Journal, vol. 1, no. 4082, pp. 671-672, 1939.

[3] A. D. Speransky, A Basis for the Theory of Medicine, International Publishers, New York, USA, 1943.

[4] L. Winter, "Intravenous procaine infusions in the postoperative period," Annals of Surgery, vol. 132, no. 1, pp. 143-146, 1950.

[5] J. Dos Ghali, J. S. Bourdin, and G. Guiot, "Injections intravéneuses de novocaïne dans les dyspnées," Bulletins et Mémoires de la Société Médicale des Hôpitaux de Paris, vol. 57, p. 741, 1941.

[6] P. Lüth, "Über die Allgemeinwirkung des Procains in ihrem Zusammenhang mit dem Gehirnstoffwechsel," Ärzneimittel Forschung, vol. 4, pp. 177-186, 1959.

[7] R. Hazard, "Une nouvelle preuve fonctionnelle, l'évaluation de la procainesterase sanguine," La Presse Médicale, vol. 56, p. $529,1948$.

[8] D. Danielopolu and E. Simionescu, "Influența novocainei (procainei) asupra acțiunii acetilcolinei, ionului $\mathrm{K}$, ionului Ca, și histaminei," Buletinul Științific al Academiei RPR, Secțiunea de Științe Medicale, vol. 1, no. 6, p. 549, 1949.

[9] C. I. Parhon and A. Aslan, Novocaina - Factor Eutrofic şi Întineritor în Tratamentul Profilactic și Curativ al Bătrâneții, Editura Academiei Republicii Populare Române, Bucharest, 1955.

[10] A. Aslan, "Eine Neue Methode zur Prophylaxe und Behandlung des Alterns mit Novokain-Stoff H3 Eutrophische und Verjungende Wirkung," in Therapiewoche, vol. 7, no. 1-2, pp. 14-22, 1956.
[11] A. Aslan, "Novocaine as a eutrophic factor and the possibility of a lengthening of the life span," Therapeutische Umschau, vol. 13, no. 9, pp. 165-172, 1956.

[12] A. Aslan, "Procaine therapy in old age and other disorders (Novocaine factor H3)," Gerontologia Clinica (Basel), vol. 2, no. 3, pp. 148-176, 1960.

[13] A. Ostfeld, C. M. Smith, and B. A. Stotsky, "The systemic use of procaine in the treatment of the elderly: a review," Journal of the American Geriatrics Society, vol. 25, no. 1, pp. 1-19, 1977.

[14] The Cochrane Collaboration, S. Szatmári, and D. Bereczki, "Procaine treatments for cognition and dementia," Cochrane Database of Systematic Reviews, vol. 4, article CD005993, 2006.

[15] T. Perls, "The reappearance of procaine hydrochloride (Gerovital H3) for antiaging," Journal of the American Geriatrics Society, vol. 61, no. 6, pp. 1024-1025, 2013.

[16] C. E. Ruse and S. G. Parker, "Molecular genetics and agerelated disease," Age and Ageing, vol. 30, no. 6, pp. 449-454, 2001.

[17] T. Niccoli and L. Partridge, "Ageing as a risk factor for disease,” Current Biology, vol. 22, no. 17, pp. R741-R752, 2012.

[18] S. Morsli and I. Bellantuono, "The use of geroprotectors to prevent multimorbidity: opportunities and challenges," Mechanisms of Ageing and Development, vol. 193, article 111391, 2021.

[19] A. Moskalev, E. Chernyagina, J. P. de Magalhães et al., "Geroprotectors.org: a new, structured and curated database of current therapeutic interventions in aging and age-related disease," Aging (Albany NY), vol. 7, no. 9, article 100799, pp. 616-628, 2015.

[20] A. Moskalev, E. Chernyagina, V. Tsvetkov et al., "Developing criteria for evaluation of geroprotectors as a key stage toward translation to the clinic," Aging Cell, vol. 15, no. 3, pp. 407$415,2016$.

[21] D. Harman, "Aging: a theory based on free radical and radiation chemistry," Journal of Gerontology, vol. 11, no. 3, pp. 298-300, 1956.

[22] C. Rusu and E. Lupeanu, "Inhibitory effect of procaine, Gerovital $\mathrm{H} 3$ and Aslavital on the production of superoxide radical," Romanian Journal of Gerontology and Geriatrics, vol. 10, pp. 117-129, 1989.

[23] C. Rusu, C. Borsa, D. Gradinaru, and C. Ionescu, "Gerovital $\mathrm{H} 3$ effect on the peroxidation potential and superoxide dismutase activity in rat liver, brain and kidney homogenates," Romanian Journal of Gerontology and Geriatrics, vol. 13, pp. 93-100, 1992.

[24] C. Rusu, C. Borsa, D. Gradinaru, C. Ionescu, and S. Babeanu, "Antioxidant and lipid-lowering effects of the original procaine-based products," Romanian Journal of Gerontology and Geriatrics, vol. 18, pp. 47-62, 1996.

[25] D. Gradinaru, D. Margina, and C. Borsa, "In vitro studies regarding the antioxidant effects of procaine, Gerovital $\mathrm{H} 3$ and Aslavital," Revue Roumaine de Chimie, vol. 54, no. 9, pp. 761-766, 2009.

[26] J. M. Lee, J. K. Suh, J. S. Jeong, S. Y. Cho, and D. W. Kim, "Antioxidant effect of lidocaine and procaine on reactive oxygen species-induced endothelial dysfunction in the rabbit abdominal aorta," Korean Journal of Anesthesiology, vol. 59, no. 2, pp. 104-110, 2010. 
[27] T. Librowski and A. Moniczewski, "Strong antioxidant activity of carane derivatives," Pharmacological Reports, vol. 62, no. 1, pp. 178-184, 2010.

[28] Z. Qiang, W. Yu, and Y. Yu, "Design and development of novel 1,3,5-triazine-procaine derivatives as protective agent against myocardial ischemia/reperfusion injury via inhibitor of nuclear factor- $\kappa \mathrm{B}$," Pharmacology, vol. 104, no. 3-4, pp. 126-138, 2019.

[29] A. Ungurianu, D. Margina, C. Borsa et al., "The radioprotective effect of procaine and procaine-derived product Gerovital H3 in lymphocytes from young and aged individuals," Oxidative Medicine and Cellular Longevity, vol. 2020, Article ID 3580934, 10 pages, 2020.

[30] A. Aslan, "Theoretical bases of procaine therapy (Gerovital $\mathrm{H} 3$ and Aslavital) in the prophylaxis of aging," Romanian Journal of Gerontology and Geriatrics, vol. 1, pp. 5-15, 1980.

[31] R. Oettmeier, U. Reuter, and L. B. P. Bonilla, "The procainebase-infusion: 20 years of experience of an alternative use with several therapeutical effects," Journal of Alternative, Complementary \& Integrative Medicine, vol. 5, no. 61, 2019.

[32] F. Bai, R. Michel, and P. Rossignol, "Effects of procaine on the oxidative phosphorylation of brain mitochondria from senescent rats," Mechanisms of Ageing and Development, vol. 26, no. 2-3, pp. 277-282, 1984.

[33] C. Tarba and C. Cracium, "A comparative study of the effects of procaine, lidocaine, tetracaine and dibucaine on the functions and ultrastructure of isolated rat liver mitochondria," Biochimica et Biophysica Acta, vol. 1019, no. 1, pp. 19-28, 1990.

[34] E. La Monaca and V. Fodale, "Effects of anesthetics on mitochondrial signaling and function," Current Drug Safety, vol. 7, no. 2, pp. 126-139, 2012.

[35] J. Xu, L. Lecanu, Z. Han, Z. Yao, J. Greeson, and V. Papadopoulos, "Inhibition of adrenal cortical steroid formation by procaine is mediated by reduction of the cAMPinduced 3-hydroxy-3-methylglutaryl-coenzyme A reductase messenger ribonucleic acid levels," The Journal of Pharmacology and Experimental Therapeutics, vol. 307, no. 3, pp. 11481157, 2003.

[36] M. D. MacFarlane, "Procaine $\mathrm{HCl}$ (Gerovital H3): a weak, reversible, fully competitive inhibitor of monoamine oxidase," Federation Proceedings, vol. 34, no. 1, pp. 108-110, 1975.

[37] J. Wu, Q. Liu, Y. Hu, W. Wang, and X. Gao, "Discovery of novel procaine-imidazole derivative as inhibitor of monoamine oxidase-B for potential benefit in Parkinson's disease," Chemistry Select, vol. 5, no. 35, pp. 10928-10932, 2020.

[38] A. Villar-Garea, M. F. Fraga, J. Espada, and M. Esteller, "Procaine is a DNA-demethylating agent with growth-inhibitory effects in human cancer cells," Cancer Research, vol. 63, no. 16, pp. 4984-4989, 2003.

[39] K. Anier, M. Urb, K. Kipper et al., "Cocaine-induced epigenetic DNA modification in mouse addiction-specific and non-specific tissues," Neuropharmacology, vol. 139, pp. 1325, 2018.

[40] N. A. B. Schumann, A. S. Mendonça, M. M. Silveira et al., "Procaine and S-adenosyl-l-homocysteine affect the expression of genes related to the epigenetic machinery and change the DNA methylation status of in vitro cultured bovine skin fibroblasts," DNA and Cell Biology, vol. 39, no. 1, pp. 37-49, 2020.
[41] X. Fan, H. Yang, C. Zhao et al., "Local anesthetics impair the growth and self-renewal of glioblastoma stem cells by inhibiting ZDHHC15-mediated GP130 palmitoylation," Stem Cell Research \& Therapy, vol. 12, no. 1, p. 107, 2021.

[42] A. Scholz, "Mechanisms of (local) anaesthetics on voltagegated sodium and other ion channels," British Journal of Anaesthesia, vol. 89, no. 1, pp. 52-61, 2002.

[43] I. B. Taylor, A. B. Stearns, H. C. Kortz, J. C. Henderson, L. E. Sioler, and E. C. Nolte, "Intravenous procaine-an adjuvant to general anesthesia; a preliminary report," Anesthesiology, vol. 11, no. 2, pp. 185-198, 1950.

[44] S. Wiedling and C. Tegnér, "7 Local Anaesthetics," Progress in Medicinal Chemistry, vol. 3, pp. 332-398, 1963.

[45] T. Kasaba, S. Onizuka, and M. Takasaki, "Procaine and mepivacaine have less toxicity in vitro than other clinically used local anesthetics," Anesthesia \& Analgesia, vol. 97, no. 1, pp. 85-90, table of contents, 2003.

[46] K. Soehring, "Novocain - eine Wirkung und Anwendung," Die Pharmazie, vol. 4, no. 7, pp. 319-325, 1949.

[47] P. Gordon, J. Fudema, and A. Abrams, "Effects of Romanian and American procaine preparations on certain physiological aspects of ageing," Excerpta Medica, vol. 20, no. 7, p. 51, 1964.

[48] P. Lüth, “Aslan-therapie mit Gero-H3," Zeitschrift für Allgemeinmedizin, vol. 60, no. 27, pp. 1162-1164, 1984.

[49] A. B. Seifen, A. A. Ferrari, E. E. Seifen, D. S. Thompson, and J. Chapman, "Pharmacokinetics of intravenous procaine infusion in humans," Anesthesia and Analgesia, vol. 58, no. 5, pp. 382-386, 1979.

[50] B. Li, M. Sedlacek, I. Manoharan et al., "Butyrylcholinesterase, paraoxonase, and albumin esterase, but not carboxylesterase, are present in human plasma," Biochemical Pharmacology, vol. 70, no. 11, pp. 1673-1684, 2005.

[51] M. Inoue, M. Morikawa, M. Tsuboi, Y. Ito, and M. Sugiura, "Comparative study of human intestinal and hepatic esterases as related to enzymatic properties and hydrolizing activity for ester-type drugs," Japanese Journal of Pharmacology, vol. 30, no. 4, pp. 529-535, 1980.

[52] S. Takai, A. Matsuda, Y. Usami et al., "Hydrolytic profile for ester- or amide-linkage by carboxylesterases pI 5.3 and 4.5 from human liver," Biological \& Pharmaceutical Bulletin, vol. 20, no. 8, pp. 869-873, 1997.

[53] J. F. Butterworth, P. A. Lief, and G. R. Strichartz, "The pHdependent local anesthetic activity of diethylaminoethanol, a procaine metabolite," Anesthesiology, vol. 68, no. 4, pp. 501-506, 1988.

[54] M. Kietzmann and K. Kaemmerer, "Effect of procaine and procaine metabolites on coenzyme A and acetyl coenzyme A concentration in various tissues of the rat," Zeitschrift für Alternsforschung, vol. 44, no. 4, pp. 211-217, 1989.

[55] C. C. Pfeiffer, E. H. Jenney, W. Gallagher et al., "Stimulant effect of 2-dimethylaminoethanol; possible precursor of brain acetylcholine," Science, vol. 126, no. 3274, pp. 610-611, 1957.

[56] J. K. Blusztajn, M. Liscovitch, C. Mauron, U. I. Richardson, and R. J. Wurtman, "Phosphatidylcholine as a precursor of choline for acetylcholine synthesis," Journal of Neural Transmission. Supplementum, vol. 24, pp. 247-259, 1987.

[57] R. Massarelli, C. Andriamampandry, N. E. Haidar et al., "The conversion of ethanolamine containing compounds to choline derivatives and acetylcholine," in Phospholipids and Signal Transmission, pp. 281-299, Springer, Berlin, Heidelberg, 1993. 
[58] D. Harman, "Free radical theory of aging: an update: increasing the functional life span," Annals of the New York Academy of Sciences, vol. 1067, no. 1, pp. 10-21, 2006.

[59] K. C. Kregel and H. J. Zhang, "An integrated view of oxidative stress in aging: basic mechanisms, functional effects, and pathological considerations," American Journal of Physiology. Regulatory, Integrative and Comparative Physiology, vol. 292, no. 1, pp. R18-R36, 2007.

[60] H. Sies, "Oxidative stress: a concept in redox biology and medicine," Redox Biology, vol. 4, pp. 180-183, 2015.

[61] A. W. K. Yeung, N. T. Tzvetkov, O. S. el-Tawil, S. G. Bungău, M. M. Abdel-Daim, and A. G. Atanasov, "Antioxidants: scientific literature landscape analysis," Oxidative Medicine and Cellular Longevity, vol. 2019, Article ID 8278454, 11 pages, 2019.

[62] M. Katerji, M. Filippova, and P. Duerksen-Hughes, "Approaches and methods to measure oxidative stress in clinical samples: research applications in the cancer field," Oxidative Medicine and Cellular Longevity, vol. 2019, Article ID 1279250, 29 pages, 2019.

[63] N. Bibi Sadeer, D. Montesano, S. Albrizio, G. Zengin, and M. F. Mahomoodally, "The versatility of antioxidant assays in food science and safety-chemistry, applications, strengths, and limitations," Antioxidants (Basel), vol. 9, no. 8, p. 709, 2020.

[64] A. Jinnouchi, Y. Aida, K. Nozoe, K. Maeda, and M. J. Pabst, "Local anesthetics inhibit priming of neutrophils by lipopolysaccharide for enhanced release of superoxide: suppression of cytochrome b558 expression by disparate mechanisms," Journal of Leukocyte Biology, vol. 78, no. 6, pp. 1356-1365, 2005.

[65] K. Takaishi, H. Kitahata, and S. Kawahito, "Local anesthetics inhibit nitric oxide production and L-arginine uptake in cultured bovine aortic endothelial cells," European Journal of Pharmacology, vol. 704, no. 1-3, pp. 58-63, 2013.

[66] B. Schuster, A. Ellmann, T. Mayo et al., "Rate of individuals with clearly increased radiosensitivity rise with age both in healthy individuals and in cancer patients," BMC Geriatrics, vol. 18, no. 1, p. 105, 2018.

[67] P. Bautista-Niño, E. Portilla-Fernandez, D. Vaughan, A. Danser, and A. Roks, "DNA damage: a main determinant of vascular aging," International Journal of Molecular Sciences, vol. 17, no. 5, p. 748, 2016.

[68] L. Hernández, M. Terradas, J. Camps, M. Martín, L. Tusell, and A. Genescà, "Aging and radiation: bad companions," Aging Cell, vol. 14, no. 2, pp. 153-161, 2015.

[69] C. Garm, M. Moreno-Villanueva, A. Bürkle et al., "Age and gender effects on DNA strand break repair in peripheral blood mononuclear cells," Aging Cell, vol. 12, no. 1, pp. 5866, 2013.

[70] G. López-Lluch, C. Santos-Ocaña, J. A. Sánchez-Alcázar et al., "Mitochondrial responsibility in ageing process: innocent, suspect or guilty," Biogerontology, vol. 16, no. 5, article 9585, pp. 599-620, 2015.

[71] E. J. Anderson, L. A. Katunga, and M. S. Willis, "Mitochondria as a source and target of lipid peroxidation products in healthy and diseased heart," Clinical and Experimental Pharmacology \& Physiology, vol. 39, no. 2, pp. 179-193, 2012.

[72] A. Bindoli, "Lipid peroxidation in mitochondria," Free Radical Biology \& Medicine, vol. 5, no. 4, pp. 247-261, 1988.
[73] K. B. Beckman and B. N. Ames, "Mitochondrial aging: open questions," Annals of the New York Academy of Sciences, vol. 854, no. 1 TOWARDS PROLO, pp. 118-127, 1998.

[74] R. S. Balaban, S. Nemoto, and T. Finkel, "Mitochondria, oxidants, and aging," Cell, vol. 120, no. 4, pp. 483-495, 2005.

[75] O. S. Ademowo, H. K. I. Dias, D. G. A. Burton, and H. R. Griffiths, "Lipid (per) oxidation in mitochondria: an emerging target in the ageing process?," Biogerontology, vol. 18, no. 6, pp. 859-879, 2017.

[76] S. Kuka, Z. Tatarkova, P. Racay, J. Lehotsky, D. Dobrota, and P. Kaplan, "Effect of aging on formation of reactive oxygen species by mitochondria of rat heart," General Physiology and Biophysics, vol. 32, no. 3, pp. 415-420, 2013.

[77] Y. Liu, G. Fiskum, and D. Schubert, "Generation of reactive oxygen species by the mitochondrial electron transport chain," Journal of Neurochemistry, vol. 80, no. 5, pp. 780787, 2002.

[78] G. Lenaz, "Role of mitochondria in oxidative stress and ageing," Biochimica et Biophysica Acta, vol. 1366, no. 1-2, pp. 53-67, 1998.

[79] P. Seeman, "The membrane actions of anesthetics and tranquilizers," Pharmacological Reviews, vol. 24, no. 4, pp. 583655, 1972.

[80] K. Noda, "The mode of action of procaine hydrochloride, viewed from $45 \mathrm{Ca}$ ion association with the membrane sites of the sartorius muscle fibres," The Kurume Medical Journal, vol. 18, no. 2, pp. 71-81, 1971.

[81] M. P. Blaustein and D. E. Goldman, "Competitive action of calcium and procaine on lobster axon. A study of the mechanism of action of certain local anesthetics," The Journal of General Physiology, vol. 49, no. 5, pp. 1043-1063, 1966.

[82] E. Lupeanu, "Influence of procaine and Gerovital H3 treatment on fatty acids oxidation in rat liver of different ages," Romanian Journal of Gerontology and Geriatrics, vol. 22, pp. 27-34, 2000.

[83] M. J. de Klaver, G. S. Weingart, T. G. Obrig, and G. F. Rich, "Local anesthetic-induced protection against lipopolysaccharide-induced injury in endothelial cells: the role of mitochondrial adenosine triphosphate-sensitive potassium channels," Anesthesia and Analgesia, vol. 102, no. 4, pp. 1108-1113, 2006.

[84] C. Rusu, "In vitro studies concerning procaine and Gerovital $\mathrm{H} 3$ effect on some mitochondria functions," Romanian Journal of Gerontology and Geriatrics, vol. 11, pp. 217-225, 1990.

[85] A. Zicca, S. Cafaggi, M. A. Mariggiò et al., "Reduction of cisplatin hepatotoxicity by procainamide hydrochloride in rats," European Journal of Pharmacology, vol. 442, no. 3, pp. 265272, 2002.

[86] J. G. Zhang and W. E. Lindup, "Effects of procaine and two of its metabolites on cisplatin-induced kidney injury in vitro: mitochondrial aspects," Toxicology In Vitro, vol. 8, no. 3, pp. 477-481, 1994.

[87] S. Onizuka, R. Tamura, N. Hosokawa, Y. Kawasaki, and I. Tsuneyoshi, "Local anesthetics depolarize mitochondrial membrane potential by intracellular alkalization in rat dorsal root ganglion neurons," Anesthesia and Analgesia, vol. 111, no. 3, pp. 775-783, 2010.

[88] X. J. Yu, Y. J. Li, Y. J. Li et al., "Neurotoxicity comparison of two types of local anaesthetics: amide- bupivacaine versus ester-procaine," Scientific Reports, vol. 7, no. 1, article 45316, 2017. 
[89] E. Lupeanu, "Effect of procaine and Gerovital H3 treatment on purine catabolism in aging," Romanian Journal of Gerontology and Geriatrics, vol. 21, pp. 22-32, 1999.

[90] V. Radaceanu, C. Matei-Vladescu, and A. Petrescu, "The effect of Gerovital $\mathrm{H} 3$ on the lipofuscin accumulation in neurons of old rat cerebral cortex. Fluorescence and electron microscopy studies," Romanian Journal of Gerontology and Geriatrics, vol. 12, pp. 211-225, 1991.

[91] F. Revnic, "The electron-microscopic aspects of hepatocyte aging in Wistar rats. The influence of GH3 treatment," Romanian Journal of Gerontology and Geriatrics, vol. 11, pp. 225-321, 1990.

[92] N. A. Le, "Lipoprotein-associated oxidative stress: a new twist to the postprandial hypothesis," International Journal of Molecular Sciences, vol. 16, no. 1, pp. 401-419, 2014.

[93] H. Katouah, A. Chen, I. Othman, and S. P. Gieseg, "Oxidised low density lipoprotein causes human macrophage cell death through oxidant generation and inhibition of key catabolic enzymes," The International Journal of Biochemistry \& Cell Biology, vol. 67, pp. 34-42, 2015.

[94] D. Gradinaru, C. Borsa, C. Ionescu, and G. I. Prada, “Oxidized LDL and NO synthesis-biomarkers of endothelial dysfunction and ageing," Mechanisms of Ageing and Development, vol. 151, pp. 101-113, 2015.

[95] H. Hammerl and O. Pichler, "Uber den Einfluss einer Novokain-Vitamin-Kombination auf die Serumlipoide bei Alternskrankheiten," Wiener Zeitschrift für innere Medizin und ihre Grenzgebiete, vol. 42, pp. 189-195, 1961.

[96] A. Aslan, C. Matei, V. Radaceanu, and G. Apostol, "The effects of the preventive and curative Aslavital treatment on experimental athero-arteriosclerosis in rabbits. I. Effects on the time course of the development of hypercholesterolemia and hypertriglyceridemia," Romanian Journal of Gerontology and Geriatrics, vol. 5, pp. 171-182, 1984.

[97] F. P. Bell and E. V. Hubert, "Effect of local anesthetics on sterol biosynthesis and sterol esterification in rat liver in vitro," Biochimica et Biophysica Acta, vol. 619, no. 2, pp. 302-307, 1980.

[98] F. P. Bell, "The effect of local anesthetics on arterial lipid metabolism: inhibition of sterol esterification in vitro," Atherosclerosis, vol. 38, no. 1-2, pp. 81-88, 1981.

[99] W. W. Zung, D. Gianturco, E. Pfeiffer et al., "Pharmacology of depression in the aged: evaluation of Gerovital $\mathrm{H} 3$ as an antidepressant drug," Psychosomatics, vol. 15, no. 3, pp. 127-131, 1974.

[100] A. Aslan, C. Balaceanu, M. Covic, M. Vrabiescu, and A. Manoiu, "La therapie Aslan dans les syndromes cerebroorganiques," Romanian Journal of Gerontology and Geriatrics, vol. 10, no. 1, pp. 83-93, 1989.

[101] V. Dobre, V. Radaceanu, R. Becheru, and S. Cofaru, "The influence of Gerovital H3 on noradrenalin, dopamine, serotonin levels and of their main metabolites in Wistar rat brain," Romanian Journal of Gerontology and Geriatrics, vol. 17, pp. 34-46, 1996.

[102] J. D. Hahn-Godeffroy, S. Mangold, M. Bernert, A. Bartelt, and T. Herdegen, "Langanhaltende Besserung von somatischen und psychovegetativen Störungen unter Procain-Infusionen: Eine multizentrische Anwendungsbeobachtung," Complementary medicine research, vol. 26, no. 1, pp. 13-21, 2019.

[103] H. Haller, F. J. Saha, B. Ebner et al., "Emotional release and physical symptom improvement: a qualitative analysis of self-reported outcomes and mechanisms in patients treated with neural therapy," BMC Complementary and Alternative Medicine, vol. 18, no. 1, p. 311, 2018.

[104] G. Xu, Z. Cao, M. Shariff et al., "Effects of G.H.3. On mental symptoms and health-related quality of life among older adults: results of a three-month follow-Up study in Shanghai, China," Nutrition Journal, vol. 15, no. 1, p. 9, 2016.

[105] C. Bălăceanu-Stolnici, M. Covic, A. Mănoiu, M. Vräbiescu, and A. Aslan, "Double blind study concerning the antidepressive effects and the clinical tolerance of Gerovital H3 without potassium metabisulphate," Romanian Journal of Gerontology and Geriatrics, vol. 17, pp. 46-62, 1996.

[106] Y. Santin, J. Resta, A. Parini, and J. Mialet-Perez, "Monoamine oxidases in age-associated diseases: new perspectives for old enzymes," Ageing Research Reviews, vol. 66, article 101256, 2021

[107] D. S. Robinson, "Changes in monoamine oxidase and monoamines with human development and aging," Federation Proceedings, vol. 34, no. 1, pp. 103-107, 1975.

[108] D. Maggiorani, N. Manzella, D. E. Edmondson et al., "Monoamine oxidases, oxidative stress, and altered mitochondrial dynamics in cardiac ageing," Oxidative Medicine and Cellular Longevity, vol. 2017, Article ID 3017947, 8 pages, 2017.

[109] F. J. Philpot, "The inhibition of adrenaline oxidation by local anaesthetics," The Journal of Physiology, vol. 97, no. 3, pp. 301-307, 1940.

[110] J. P. Hrachovec, "Inhibitory effect of Gerovital H3 on rat brain monoamine oxidase," Federation Proceedings, vol. 31, no. 2, p. 604, 1972.

[111] D. Bhaskaran and E. Radha, "Murine regional brain monoamine oxidase activity: time- and age-dependent response to inhibitors," Gerontology, vol. 30, no. 2, pp. 87-93, 1984.

[112] M. D. MacFarlane and H. Besbris, "Procaine (Gerovital H3) therapy: mechanism of inhibition of monoamine oxidase," Journal of the American Geriatrics Society, vol. 22, no. 8, pp. 365-371, 1974.

[113] V. Stroescu, P. Gane, I. Constantinescu, and A. Vrabiescu, "Biochemical and pharmacodynamic arguments to support procaine IMAO-B type actio," Romanian Journal of Gerontology and Geriatrics, vol. 1, pp. 55-61, 1980.

[114] H. Yasuhara, I. Wada, K. Sakamoto, and K. Kamijo, "Effects of local anesthetics on monoamine oxidase, and their membrane effects," Japanese Journal of Pharmacology, vol. 32, no. 2, pp. 213-219, 1982.

[115] C. Borsa, C. Rusu, D. Gradinaru, and C. Ionescu, "Gerovital new formula and Aslavital effect on monoamine oxidase activity in mitochondrial fraction from rat liver and brain," Romanian Journal of Gerontology and Geriatrics, vol. 24, pp. 7-23, 2002.

[116] L. Lecanu, Y. Wenguo, J. Xu, J. Greeson, and V. Papadopoulos, "Local anesthetic procaine protects rat pheochromocytoma PC12 cells against beta-amyloid-induced neurotoxicity," Pharmacology, vol. 74, no. 2, pp. 65-78, 2005.

[117] D. Li, Y. Yan, L. Yu, and Y. Duan, "Procaine attenuates pain behaviors of neuropathic pain model rats possibly via inhibiting JAK2/STAT3," Biomolecules \& therapeutics, vol. 24, no. 5, pp. 489-494, 2016.

[118] L. Bucci, "Procaine: a monoamine oxidase inhibitor in schizophrenia," Diseases of the Nervous System, vol. 34, no. 7, pp. 389-391, 1973. 
[119] T. M. Yau, Gerovital H3, monoamine oxidase and brain monoamines, in Theoretical Aspects of Aging, Academic Press Inc, 1974.

[120] A. Ankay Yilbas, B. Akca, B. Buyukakkus et al., "Procaine and saline have similar effects on articular cartilage and synovium in rat knee," BMC Anesthesiology, vol. 18, no. 1, p. 51, 2018.

[121] T. Takenami, G. Wang, Y. Nara et al., "Intrathecally administered ropivacaine is less neurotoxic than procaine, bupivacaine, and levobupivacaine in a rat spinal model," Canadian Journal of Anaesthesia, vol. 59, no. 5, pp. 456-465, 2012.

[122] R. Ghafari, A. G. Baradari, A. Firouzian et al., "Cognitive deficit in first-time coronary artery bypass graft patients: a randomized clinical trial of lidocaine versus procaine hydrochloride," Perfusion, vol. 27, no. 4, pp. 320-325, 2012.

[123] The Cochrane Collaboration, D. Zaric, C. Christiansen, N. L. Pace, and Y. Punjasawadwong, "Transient neurologic symptoms (TNS) following spinal anaesthesia with lidocaine versus other local anaesthetics," Cochrane Database of Systematic Reviews, vol. 2, article CD003006, 2009.

[124] M. Zampieri, F. Ciccarone, R. Calabrese, C. Franceschi, A. Bürkle, and P. Caiafa, "Reconfiguration of DNA methylation in aging," Mechanisms of Ageing and Development, vol. 151, pp. 60-70, 2015.

[125] A. Bürkle, M. Moreno-Villanueva, J. Bernhard et al., "MARK-AGE biomarkers of ageing," Mechanisms of Ageing and Development, vol. 151, pp. 2-12, 2015.

[126] V. Singh, P. Sharma, and N. Capalash, "DNA methyltransferase-1 inhibitors as epigenetic therapy for cancer," Current Cancer Drug Targets, vol. 13, no. 4, pp. 379399, 2013.

[127] X. Fan, D. Wang, X. Chen, and R. Wang, "Effects of anesthesia on postoperative recurrence and metastasis of malignant tumors," Cancer Management and Research, vol. 12, pp. 7619-7633, 2020.

[128] H. Liu, J. P. Dilger, and J. Lin, "Effects of local anesthetics on cancer cells," Pharmacology \& Therapeutics, vol. 212, article 107558, 2020.

[129] F. Moreira-Silva, V. Camilo, V. Gaspar, J. F. Mano, R. Henrique, and C. Jerónimo, "Repurposing old drugs into new epigenetic inhibitors: promising candidates for cancer treatment?," Pharmaceutics, vol. 12, no. 5, p. 410, 2020.

[130] Z. Gao, Z. Xu, M. S. Hung et al., "Procaine and procainamide inhibit the Wnt canonical pathway by promoter demethylation of WIF-1 in lung cancer cells," Oncology Reports, vol. 22, no. 6, pp. 1479-1484, 2009.

[131] M. Tada, F. Imazeki, K. Fukai et al., "Procaine inhibits the proliferation and DNA methylation in human hepatoma cells," Hepatology International, vol. 1, no. 3, pp. 355-364, 2007.

[132] S. Castellano, D. Kuck, M. Sala, E. Novellino, F. Lyko, and G. Sbardella, "Constrained analogues of procaine as novel small molecule inhibitors of DNA methyltransferase-1," Journal of Medicinal Chemistry, vol. 51, no. 7, pp. 23212325, 2008.

[133] M. S. Ali, M. A. Farah, H. A. al-Lohedan, and K. M. al-Anazi, "Comprehensive exploration of the anticancer activities of procaine and its binding with calf thymus DNA: a multi spectroscopic and molecular modelling study," RSC Advances, vol. 8, no. 17, pp. 9083-9093, 2018.

[134] Y. C. Li, Y. Wang, D. D. Li, Y. Zhang, T. C. Zhao, and C. F. Li, "Procaine is a specific DNA methylation inhibitor with anti- tumor effect for human gastric cancer," Journal of Cellular Biochemistry, vol. 119, no. 2, pp. 2440-2449, 2018.

[135] B. Ying, H. Huang, H. Li, M. Song, S. Wu, and H. Ying, "Procaine inhibits proliferation and migration and promotes cell apoptosis in osteosarcoma cells by upregulation of microRNA-133b," Oncology Research, vol. 25, no. 9, pp. 14631470, 2017.

[136] C. Li, S. Gao, X. Li, C. Li, and L. Ma, "Procaine inhibits the proliferation and migration of colon cancer cells through inactivation of the ERK/MAPK/FAK pathways by regulation of RhoA," Oncology Research, vol. 26, no. 2, pp. 209-217, 2018.

[137] X. W. Ma, Y. Li, X. C. Han, and Q. Z. Xin, "The effect of low dosage of procaine on lung cancer cell proliferation," European Review for Medical and Pharmacological Sciences, vol. 20, no. 22, pp. 4791-4795, 2016.

[138] V. Borutinskaite, J. Bauraite-Akatova, and R. Navakauskiene, "Anti-leukemic activity of DNA methyltransferase inhibitor procaine targeted on human leukaemia cells," Open Life Sciences, vol. 11, no. 1, pp. 322-330, 2016.

[139] S. Ran, C. Li-Ping, W. Kai-Chen, S. Hong-yan, and C. Xianling, "Procaine inhibiting human bladder cancer cell proliferation by inducing apoptosis and demethylating APAF1 CpG island hypermethylated," Chemical Research in Chinese Universities, vol. 28, no. 6, pp. 1017-1021, 2017.

[140] A. Aslan, A. Vrabiescu, C. Domilescu, L. Campeanu, M. Costiniu, and S. Stanescu, "Long-term treatment with procaine (Gerovital H3) in albino rats," Journal of Gerontology, vol. 20, no. 1, pp. 1-8, 1965.

[141] A. Aslan, A. Vrabiescu, and G. Acalugăriței, "New data concerning the action of Gerovital $\mathrm{H} 3$ on the lifespan of Wistar rats," Romanian Journal of Gerontology Geriatrics, vol. 1, pp. 273-279, 1980.

[142] A. Aslan, A. Vrăbiescu, and C. Strungaru, "The influence of Gerovital H3 treatment on longevity in Drosophila melanogaster," Romanian Journal of Gerontology Geriatrics, vol. 6, pp. 24-31, 1986.

[143] D. E. Becker and K. L. Reed, "Local anesthetics: review of pharmacological considerations," Anesthesia Progress, vol. 59, no. 2, pp. 90-102, 2012.

[144] P. Lirk, R. Berger, M. W. Hollmann, and H. Fiegl, "Lidocaine time- and dose-dependently demethylates deoxyribonucleic acid in breast cancer cell lines_in vitro_ †," British Journal of Anaesthesia, vol. 109, no. 2, pp. 200-207, 2012.

[145] H. Sabit, M. B. Samy, O. A. M. Said, and M. M. el-Zawahri, "Procaine induces epigenetic changes in HCT116 colon cancer cells," Genetics research international, vol. 2016, Article ID 8348450, 7 pages, 2016. 